\title{
Overconfidence and narcissism among the upper echelons: a systematic literature review
}

\author{
Johannes Brunzel ${ }^{1}[$ ]
}

Received: 28 April 2020 / Accepted: 13 August 2020 / Published online: 27 August 2020

(C) The Author(s) 2020

\begin{abstract}
Research has been trying to analyze cognitive decision making processes of topexecutive for decades. In particular, economic and organizational research on overconfidence (e.g., the notion that one is better than the average) and narcissism (e.g., exaggerated feeling of self-importance and the need for admiration) among the upper echelons has shown to influence firm strategies and firm level outcomes in similar ways. Yet these approaches appear in distinct research disciplines. Although both constructs are theoretically and empirically linked, and have shown to affect key organizational outcomes, surprisingly little clear empirical consensus exist how these constructs - individually and mutually - affect firm level outcomes. I try explain this puzzle by providing an overview of the leading approaches of executive overconfidence and executive narcissism research. To disentangle both constructs conceptionally and empirically, I review a large sample of articles that are nested in leading economic and business journals. Thus, I identify key operationalization issue and discuss how divergent literature streams in Economics and Organizational Behavior may benefit from each other. The review suggest that paying more attention - theoretically and empirically - to the interaction of overconfidence and narcissism may help to augment knowledge accumulation in the field. Furthermore, greater validation concerns of unobtrusive measures and its endogenous nature may help to rule out alternative explanations. Generally speaking, the results suggest that top-executive overconfidence and narcissism are not mere interesting psychological biases but affect firm-level outcomes in important ways.
\end{abstract}

Keywords Overconfidence $\cdot$ Narcissism $\cdot$ Upper-Echelon $\cdot$ Top-Executives

Electronic supplementary material The online version of this article (https://doi.org/10.1007/s1130 1-020-00194-6) contains supplementary material, which is available to authorized users.

Johannes Brunzel

brunzel.johannes@gmail.com

1 Technische Universität Braunschweig, Institut für Unternehmensführung und Organisation, Abt-Jerusalem-Str. 4, 38106 Braunschweig, Germany 


\section{JEL Classification 91E45}

\section{Introduction}

The New York Times reported in 2002 on the lawsuits against corporate executives amid a series of earnings restatements, accounting scandals and sudden bankruptcies at Enron, WorldCom, or Tyco Inc, including the \$600 million fraud scheme of former Tyco CEO Dennis Kozlowski, who was alleged of stock fraud, unauthorized bonuses and falsified expense accounts (The New York Times 2002). Given the severe economic consequence of these past incidents, unsurprisingly, practice calls for a better understanding of personal factors that led to the pandemic of bad leadership, including overconfidence and narcissism of these Chief Executive Officers (CEOs) (Allio 2007). Moreover, researchers argue that pathological characteristics of CEOs were responsible for the financial crisis (Boddy 2011) and CEOs such as Kozlowski and Skilling (Enron) are prototypical narcissists (Craig and Amernic 2011). However, contractionary finding of both overconfidence and narcissism make both constructs, independently and in conjunction, hard to understand. For instance, narcissistic CEOs may be conducive for firm level innovation (e.g., Kashmiri et al. 2017) while increasing the likelihood to be involved in corporate fraud (e.g., Rijsenbilt and Commandeur 2013), thereby providing arguments for "bad" as well as "good" outcomes of CEO narcissism. Similarly, overconfident CEOs may be also conducive for firm level innovation (Hirshleifer et al. 2012) while increasing the likelihood to undertake value-destroying M\&As (Malmendier and Tate 2005), thereby providing similar arguments for "bad" as well as "good" outcomes of CEO overconfidence. Given this evidence of contradictory findings of overconfidence and narcissism independently, further improving our "[...]understanding of the relationship between narcissism and overconfidence and especially when in positions of power, is important" (Macenczak et al. 2016, p. 113). Since overconfidence and narcissism are sometimes used interchangeably in everyday language and even academic literature (Post 1993), we lack a coherent understanding how both constructs affect firm level outcomes. As put by Navis and Ozbek (2015, p. 121): "Although scholars have begun to establish overconfidence and narcissism as individual constructs worthy of study, they have paid less attention to their mutual and conditional relevance". Moreover, despite frequent calls to incorporate narcissism and overconfidence into economic and business theory (e.g., Miller 2015; Trigeorgis and Reuer 2017) and organizational theory in general (e.g., Campbell et al. 2010), our understanding how these constructs-individually and in conjunction-affect organizational outcomes remains limited.

To fill this void, I study both constructs by applying a systematic review of the leading journals in Management and Economics from 2005 to 2018. While there is a common perception that both constructs may be used interchangeably, I argue that there are overlapping yet distinct channels by which overconfidence and narcissism among top-executives manifest in organizational outcomes. Therefore, the study aims to provide a comprehensive overview of research approaches in the field of Economics, Management and Organizational Behavior to disentangle conceptual 
and methodical underpinnings, particularly focusing on the operationalization of the constructs. The focus on operationalization issues is particularly important as previous research points to validity concerns (e.g., Hill et al. 2014). By delving into the literature of these constructs, I delineate cumulative research results and complement recent literature reviews that look on the CEO effect in general (e.g., Busenbark et al. 2016). Although previous studies focus on narcissism in organizational settings (Chatterjee and Pollock 2017; Grijalva et al. 2105a; Rosenthal and Pittinsky 2006), I am unaware of reviews linking both concepts on a top-executive level (CEO-level) in the field of Economics, Management and Organizational Behavior.

The remainder of the paper is as follows. The next section outlines evidence concerning the background and antecedents of overconfidence and narcissism research, followed by a synthesis how these constructs are related in the "general" literature. I then provide an explanation of the method how I locate the "specific" literature employed in the review. Subsequently, I provide an overview of approaches, and discuss the methodological approaches to derive implications for further research. By focusing on the application and operationalization in the field relevant to a management audience, I finally summarize and uncover future opportunities for research in our field.

\section{Defining overconfidence and narcissism}

\subsection{Background literature}

The study of executive personality characteristics remains a major stream of inquiry in Management (Hambrick and Mason 1984), Psychology (Peterson et al. 2003) and mainstream Economics (e.g., Bertrand and Schoar 2003; Graham et al. 2013). On the one hand, top executives might be constraint by institutional (Dimaggio and Powell 1983) or evolutionary forces (Nelson and Winter 1982), thereby decreasing the influence or discretion of individual decision makers (Dimaggio and Powell 1983; Finkelstein and Hambrick 1990). On the other hand, idiosyncratic demographic or functional background characteristics of the Top-Management-Team (TMT) have shown to affect organizational outcomes (Carpenter et al. 2004). As large productivity discrepancies even within narrowly defined industries (i.e. the same SIC) continue to exist (Syverson 2004), a logical step is to link these discrepancies to the person in charge of implementing them: top- executives. Put simply by Syverson (2011, p. 327): “[...] some producers seem to have figured out their business (or are least on their way), while others are woefully lacking". While the causal drivers of this heterogeneity are manifold on the supply and demand side (learning of firms, market competition, human capital, to name a few), research has pointed out what characteristics of CEOs (e.g., Kaplan et al. 2012; Kaplan and Sorensen 2017) under what contextual factors matter (Bandiera et al. 2013; Graham et al. 2013; Mullins and Schoar 2016). Although demographic and educational characteristics of CEOs remain important explanatory variables, research has progressed to go beyond directly observable characteristics of top-executives. Either by 
aggregating CEO personality dimensions with traditional means (e.g., Big 5; Five Factor model: Herrmann and Nadkarni 2014; Peterson et al. 2003), or by looking at single "bright" (e.g., humility: Ou et al. 2016) or "dark" CEO personality characteristics (see Smith et al. 2017 for a review).

The latter research stream has received considerable attention in form of executive overconfidence and executive narcissism for organizational outcomes. For instance, overconfidence may affect M\&A outcomes (e.g., Malmendier and Tate 2005), capital structure (Ben-David et al. 2013), or innovational behavior (e.g., Hirshleifer et al. 2012), while narcissism has shown to affect a variety of key organizational outcomes such as sales variance (Chatterjee and Hambrick 2007) or corporate fraud (Rijsenbilt and Commandeur 2013). Although many studies elaborate on detrimental effects of CEO overconfidence and narcissism, theoretical (Campbell et al. 2010; Maccoby 2000; Smith et al. 2017) and empirical approaches argue that overconfidence and narcissism may be beneficial in certain contexts (e.g., Hirshleifer et al. 2012; Kashmiri et al. 2017). By studying how top-executives and particularly CEOs exhibit these traits rather than other members of the Top-Management-Team (TMT), I draw on the assumption of the literature that CEOs shape the fate of companies (Finkelstein et al. 2009). No executive is more influential since personal values, personality characteristics, motives, functional background or experience-just to name a few-of the CEO determine to which internal and external cues the company pays attention to, thereby affecting strategic actions of companies (Cho and Hambrick 2006; Hambrick and Mason 1984).

\subsection{Conceptualizing overconfidence}

Overconfidence is an excess of confidence in one's abilities or judgment or confidence that is not justified (Merriam-Webster definition). Individuals are prone to exert a wide range of psychological biases (Kahneman and Tversky 1979) of whom overconfidence is one of the most powerful and prominent. People overestimate their general abilities in everyday activities (e.g., driving: Roy and Liersch 2013), think they are "better than the average" (Kruger and Dunning 1999), attribute causal relationships to own actions (Lewis and Daltroy 1990), underestimate the probability of random events (Harris et al. 2009) or underestimate risk (e.g., Campbell et al. 2004). Consequently, overconfidence has been attributed to a wide range of outcomes such as voting behavior, war and even the financial crisis in 2008 (Ho et al. 2016). In short, "the significance of overconfidence to the conduct of human affairs can hardly be overstated" (Griffin and Tversky 1992, p. 432). Chen (2010, p. 36) defines overconfidence as an inflated subjective probability of a particular outcome occurring. Interest in overconfidence as one of two focal constructs in this article, stems from its exceptional relevance for decision making in general and its application on the top-executive level in particular. Overconfident individuals tend to be outgoing (extraverted), but as well as agreeable and conscientious (Schaefer et al. 2004). Although most people exert this bias to some degree, professional managers are particularly likely to be affected by this bias than lay people (Glaser et al. 2005) due to self-selection processes. Professional managers believe they can "beat 
the odds" (Camerer and Lovallo 1999) with potentially crucial consequences on the firm level. Moore and Healy (2008) argue that the construct consists of three distinct traits. First, overestimation of one's actual performance (i.e., illusion of control). Second, overplacement of one's performance relative to others (i.e., better-thanaverage-effect). Third, excessive precision in one's belief (i.e., accuracy of confidence intervals).

In economic studies, Finance scholars were among the first to introduce the notion of CEO hubris-exaggerated self-confidence derived from Greek mythology - as a motive to pay M\&A premiums, arguing that price premiums paid by acquiring CEOs exceed rational evaluations (Roll 1986). Management scholars then demonstrated the hubris effect empirically (Hayward and Hambrick 1997) and in the context of entrepreneurship to explain high venture creation rates (Hayward et al. 2006). Since it is difficult to distinguish between hubris and overconfidence theoretically and empirically, authors such as Hayward et al. (2006) or Tang et al. (2015) argue that hubris and overconfidence can be used interchangeably.

Almost all studies posit that overconfidence can have detrimental (the dark side) and conducive implications for organizational performance. ${ }^{1}$ On the detrimental side, Hayward et al. (2006) argue that executive overconfidence explains high failure rates among new ventures. Trevelyan (2008) argues that executive overconfident may lead to ineffective and incomplete information use by thoroughly relying on mental short-cuts. Camerer and Lovallo (1999) argue in an experimental setting that overconfident executives are risk insensitive, implying that these executives are going to pursue riskier strategies in general.

On the positive side, Hayward et al. (2010) argue that more confident executives will possess greater emotional and cognitive resilience needed to pursue challenging and high risk endeavors. Overconfidence may induce faster information processing and actions by discarding disconfirming information (Trevelyan 2008). Moreover, overconfident executives may have benefits not just for internal decision making processes but also for external perceptions. This is important because leaders are dependent on external assessment by shareholders, stakeholders, media outlets or analysts. Overconfident leaders are perceived as more competent (status-enhancement) by followers even if the trait of overconfidence is revealed (Kennedy et al. 2013).

In other words, these studies point to the utility of non-rational decision making during environmental uncertainty and complexity as a coping strategy to purse uncertain outcomes and high risk strategies such as innovation or new product introductions (Busenitz and Barney 1997; Forbes 2005; Simon and Houghton 2003). The same literature indicates that overconfidence is a function of individual and contextual factors and is more likely to occur if managerial decision making is less formally and informally constrained (Busenitz and Barney 1997; Forbes 2005). Following the reasoning that cognitive self-assessments of executives can have negative

\footnotetext{
1 There is considerable research in finance covering the role of financial investors and the role of markets as reaction to overconfidence (e.g., Odean 1999; Barber and Odean 2001). This review considers the role of top-executives only.
} 
and positive manifestations, research has tried to aggregate executive's self-evaluation under one umbrella term, called executive core self-evaluation (Hiller and Hambrick 2005).

Taken together, research points to overestimation of one's abilities that departs from objective standards or the overestimation (underestimation) of cues. This will lead to overconfidence in risky, pioneering and high discretion contexts such as new product introductions, innovation strategies, or M\&As. Although much of this scholarly stream emerged from the entrepreneurship literature, it has been shown that overconfident top-executives pursue entrepreneurial actions (Engelen et al. 2015). That is, methods, practices and decision making styles to act entrepreneurially on dimensions such as autonomy, innovativeness, risk taking, proactiveness and competitive aggressiveness (Lumpkin and Dess 1996). These executives exploit novel opportunities and new product-markets, or experiment with new technologies even though ex-ante information is scarce. In general, overconfidence is greatest for difficult and ambiguous (i.e., low predictability) tasks and for actions without fast and clear feedback (see Koellinger et al. 2011 for a review).

\subsection{Conceptualizing narcissism}

Narcissism, a personality trait encompassing grandiosity, arrogance, self-absorption, entitlement, fragile self-esteem, and hostility (Rosenthal and Pittinsky 2006). The word narcissism is derived from the Greek mythology of "Narcissus" who fell in love with his own reflection, is an inflated (i.e., deviating from objective standards) yet vulnerable grandiose view of oneself (in fantasy or behavior) with the chronic goal to achieve continuous external self-affirmation (Krizan and Bushman 2011; Morf and Rhodewalt 2001). Other clinical criteria's include a lack of empathy towards others, a sense of entitlement towards favorable treatment, preoccupation with fantasies of unlimited success, power, brilliance, or beauty, as well as interpersonally exploitative and arrogant attitudes or behavior (American Psychiatric Association 2013). In order to maintain this exaggerated self-view, narcissists are attuned to the reactions of others of perceived as relevant to themselves and engage in social comparison with individuals they perceive as inferior; become preoccupied with fantasies of unlimited power and success in order to prove their "specialness" (Bogart et al. 2004). Therefore, goal setting is often unreasonably high and based on approval from others (American Psychiatric Association 2013). For Rosenthal and Pittinsky (2006), narcissism is a personality trait encompassing grandiosity, arrogance, self-absorption, entitlement, fragile self-esteem, and hostility. Narcissistic behavior is linked to basic personality dimensions such as dominance, extraversion, exhibitionism and confidence, to name a few (Emmons 1984). Hence, in the realm of top-executives, these very attributes induce leaders to appear as charismatic and visionary (Maccoby 2003), thereby helping leaders to attain and maintain influence and power. Emmons (1987, p. 16) indicates that "[...] narcissistic individuals exploit and manipulate others to increase their sense of self-worth". Consequently, narcissistic leaders have been blamed for a variety of outcomes such as the results of political campaigns (Watts et al. 2013) and the financial crisis (Shulman 2016). Like 
overconfidence, it is likely that narcissistic personalities self-select into positions with high formal and informal degree of power to reaffirm their belief in superiority (Chatterjee and Hambrick 2007; Nevicka et al. 2011). Narcissism belongs to the so called dark triad (including Psychopathy, Machiavellianism) of personality traits and is one of the most relevant traits to organizational researchers (see Campbell and Miller 2011; Spain et al. 2014).

Although narcissistic characteristics can be an extreme form of a personality disorder (NPD), it has been long recognized that narcissism ranges along a continuum as opposed to a binary state. On the one hand, Freud (1914) argues that loving oneself has the "significance of a perversion". On the other hand, it is a [...] libidinal employment to the egoism of the instinct of self-preservation, a measure of which may justifiably be attributed to every human being" (Freud 1914; p. 75). Hence, authors argue that productive or constructive narcissism exist (Maccoby 2000; Vries and Miller 1985). The positive aspects of these form may be an a secured sense of self-esteem to cope with daily frustration and stress, strive for constant improvement with high standards and effective, eloquent rhetoric and communication to followers (Lubit 2002; Maccoby 2000). Research also indicates positive aspect of individuals with weaker levels of narcissistic tendencies, describing them as grandiose, competitive, attention seeking, and provocative, while demonstrating adaptive functioning (Caligor et al. 2015). Others argue that healthy levels of narcissism-complemented by experience - are required for ambitious goals, creativity, resilience, or even empathy with others (Brown 1997; Kohut 1966). Consequently, productive or constructive narcissistic leaders appear to be more charismatic and score higher on perceived performance (Deluga 1997). Post (1986) argues that productive or constructive narcissistic leaders are a necessity, providing guidance to "ideal hungry" followers especially during societal crises. Furthermore, these productive narcissism scores play a significant role in explaining entrepreneurial intentions (Mathieu and St-Jean 2013).

Most of these studies assume that narcissistic managers share prototypical traits of a leader such as confidence, charisma, vision, optimism and persuasiveness. Therefore, narcissists are more likely to emerge as leaders in the first place and tend to stay there as a means to enhance their need for admiration. However, research is inconsistent (see Campbell et al. 2010) as to whether the costs of narcissistic leaders exceeds the benefits in organizational contexts.

\subsection{Commonalties and differences between overconfidence and narcissism}

Narcissistic executives overestimate their performance compared to actual performance, thereby closely aligning with the definition of overconfidence. Therefore, one should expect that narcissists exhibit generally a higher degree of overconfidence. There is evidence in the Psychology literature that (at least grandiose) narcissism is linked to higher levels of confidence (Campbell et al. 2002; Emmons 1984; Raskin et al. 1991). Therefore, for Post (1993, p. 99) "narcissism is nothing more than extreme self-confidence". Gabriel et al. (1994) show that narcissistic individuals (measured by the narcissistic personality inventory: NPI) are more likely to 
Table 1 Selective correlative results between dimensions of overconfidence and narcissism

\begin{tabular}{llll}
\hline Overconfidence & Narcissism & Pearson correlation & Exemplary source \\
\hline Overprecision (sub-trait) & NPI-40 & $.44^{* *}$ & Macenczak et al. (2016) \\
Overplacement (sub-trait) & NPI-40 & $.18^{* *}$ & Macenczak et al. (2016) \\
Overestimation (sub-trait) & NPI-40 & $.36^{* *}$ & Macenczak et al. (2016) \\
Overconfidence (sum) & NPI & $.28^{* *}$ (Study 1) & Campbell et al. (2004) \\
Overconfidence (sum) & NPI & $.30^{* *}$ (Study 2) & Campbell et al. (2004) \\
Overclaiming (sub-trait) & NPI & $.35^{* *}$ & Paulhus et al. (2003) \\
Intelligence enhancement(sub-trait) & NPI & $.31^{* *}$ & Paulhus et al. (2003) \\
Personality enhancement (sub-trait) & NPI & $.17^{*}$ & Paulhus et al. (2003) \\
\hline
\end{tabular}

**Correlation is significant at the 0.01 level (2-tailed)

*Correlation is significant at the 0.05 level (2-tailed)

overrate their cognitive ability and psychical attractiveness. Campbell et al. (2004) assess in an experimental student setting the actual knowledge and the confidence intervals of participants. Assessing the degree of narcissism via the (NPI), narcissism is significantly correlated with overconfidence. The authors also find that narcissism is correlated with increased risk-taking in knowledge based tasks. Similarly, Ames and Kammrath (2004) find that the discrepancy between estimates in social judgment tasks and actual performance is highest for narcissistic personalities, indicating that narcissistic participants are overconfident in their estimations. Macenczak et al. (2016) find that perceived power and narcissism explains the overconfidence construct. The authors find that their NPI measure of narcissism is significantly correlated with the overconfidence measures. After introducing power manipulation among highly narcissistic people overconfidence rates increased even more. Table 1 provides correlative results from the general literature. Since no Pearson coefficient is above the Cohen 0.5 threshold, one can conclude that both constructs are moderately related but not strongly correlated, indicating that there is sufficient variance for independent constructs.

According to Kroll et al. (2000, p. 120), narcissism is also a direct source of hubris as it "[...]derives from an overbearing sense of grandiosity, need for admiration, and self-absorption-in a word, narcissism". In this view, narcissism and hubris are interchangeable as executives seek out positions of power to satisfy their desire of admiration. In organizational settings, Hayward and Hambrick (1997) argue that the level of CEO self-importance, a key element of narcissism, is part the hubris scale and therefore explains the level of risk taking in a firms, as indicated by the price premium paid for acquisitions. Campbell et al. (2010) distinguish between vulnerable and grandiose narcissism and argue that grandiose narcissism and overconfidence share similar traits. Campbell et al. (2010, p. 270) describe a grandiose narcissist on a managerial level as someone "who is (over)confident, extraverted, high in self-esteem, dominant, attention seeking, interpersonally skilled and charming, but also unwilling to take criticism, aggressive, high in psychological entitlement, lacking in true empathy, interpersonally exploitative and grandiose or even haughty". 
Organizational researchers argue that "narcissism combines overconfidence with a strong focus on personal rewards" (Buyl et al. 2019, p. 6). Chatterjee and Hambrick (2007) argue that overconfidence and narcissism are closely related at task domains, but posit that the main difference lies in the strive for constant selfassurance from external sources to reaffirm superiority of the narcissist. They may possess some degree of overconfidence but narcissistic managers pursue personal objectives at the expense of others. Therefore, narcissism would exacerbate poor decision making compared to overconfidence (Ham et al. 2017b).

Although the direction of causality remains debatable, these arguments point out that narcissism and overconfidence are closely related and very similar. However, the distinction between both constructs seems to be a major problem. As put by O'Reilly et al. (2014, p. 2), "the difference between those who are self-confident and those who are narcissistic are often difficult to detect. Thus, it is likely that both highly self-confident and narcissistic people are disproportionally selected into CEO jobs". At its very core, narcissists' self is not grounded in objective reality and thus need constant reinforcement (Morf and Rhodewalt 2001). The departure of the self from objective reality fits well with the notion of overconfidence in which people depart from objective judgement. However, while overconfidence seems to be an overall characteristics of humans, narcissism extends this notion by drawing on the individual tendency to ensure a narcissistic supply (Fenichel 1938) from the environment in form of nontangible (e.g., attention, applause, approval, affirmation) or tangible (e.g., awards, compensation) reaffirmation of their self. Following this reasoning, managers (agents) seem to be particularly likely to deviate from shareholders (principals) interest (Jensen and Meckling 1976) when confronted with narcissistic CEOs compared to overconfident CEOs. In other words, their need for confirmation from outside in form of (media) attention, applause, approval, affirmation is used to protect their fragile self-esteem and to cover up self-doubt. This is decisive aspect of narcissism compared to overconfidence. Chatterjee and Pollock (2017) argue that narcissistic CEOs seek that acclaim mainly through celebrity in the media while they also need to dominate decision making, preferring lower status and less experienced colleagues in order to dominate. In fact, narcissistic CEOs are more likely to secure internal signs of power and glory (higher absolute and relative compensation packages) as well as external signs of power and glory (M\&A expenditures) (Chatterjee and Hambrick 2007; Ham et al. 2017b). Therefore, one can argue that narcissism is a comprehensive personality trait that affects thinking, feeling and behaving of individuals (Campbell and Foster 2007) while overconfidence as a cognitive bias relating to biased perceptions of reality (i.e. predominately affecting cognition). It is also noteworthy that overconfident individuals tend may be charming and outgoing (Schaefer et al. 2004) similar to narcissistic individuals, but they lack the exploitative character that may lead to interpersonal conflicts. In other words, overconfident individuals show extraverted behavior but can still exhibit agreeable and conscientious behavior (Schaefer et al. 2004). In addition, while overconfidence is depicted as a general cognitive bias, the literature indicates that narcissism is embedded in higher-order societal values. In other words, narcissism is more prevalent in societies in western societies compared to societies that cherish meta-values such as humility (Morris et al. 2005) while overconfidence appears to be prevalent universally across 
cultures. Finally, a commonality of overconfidence and narcissism is that both constructs are demographically dependent (age, gender, education etc.). For instance, male investors are significantly more overconfident than female investors (Bhandari and Deaves 2006) while narcissism appears to be more prevalent among male than male studies across age groups (Grijalva et al. 2015b). Table 2 provides a summary between dimensions of narcissism and overconfidence. The table indicates that the main differences between the constructs can be found in its very different applicability and reach as well as in its different regulating mechanisms.

Having provided an overview about converging and overlapping definitions in the field, I next systematically look at all published papers relating narcissism and overconfidence to organizational behavior. Thus, an overview about the conceptualization and operationalization is discussed. Although narcissism and overconfidence are multidimensional, highly complex constructs subject to distinct scholarly schools, the review is intended to cut through this complexity and to derive general conclusions.

\section{Research method}

This study uses a systematic literature review to provide an overview about different yet related perspectives nested in several research schools. I examine commonalties and distinct approaches to derive approaches for future inquiries.

\subsection{Search strategy}

The initial search strategy encompasses all articles published in the Elsevier Scopus database, a major source for academic literature. The sequential steps, including the number of retained and excludes articles, can be found in Fig. 1. I searched in the Scopus database within the title, abstract, and provided key words for articles containing the phrases "overconfidence" and "narcissism" until end of October 2017. Although other databases provide different capabilities, Scopus was chosen mainly because it is one of the major databases and shows sufficient stability on several research metrics and disciplines compared to Web to Science and Google Scholar (Harzing and Alakangas 2016). Based on theoretical evidence, I neglect synonymous words of overconfidence such as hubris as previous literature uses them interchangeably (e.g., Hayward et al. 2006). Having a rather general term such as "narcissism" enables me to capture word-stems that are related and will be consequently included (narcis covers the terms narcissist or narcissists). After having located the general field of search by using the general search term "overconfidence" or "narcissism", I use Boolean operators to specify the level of analysis (e.g., "CEO AND Narcissism"; "Top-Manager AND Narcissism", "CEO AND overconfidence”). Generating a large sample and then systemically reduce the number of articles that is feasible to analyze is a common approach to balance depth and breadth of a systemic review (Fisch and Block 2018). 


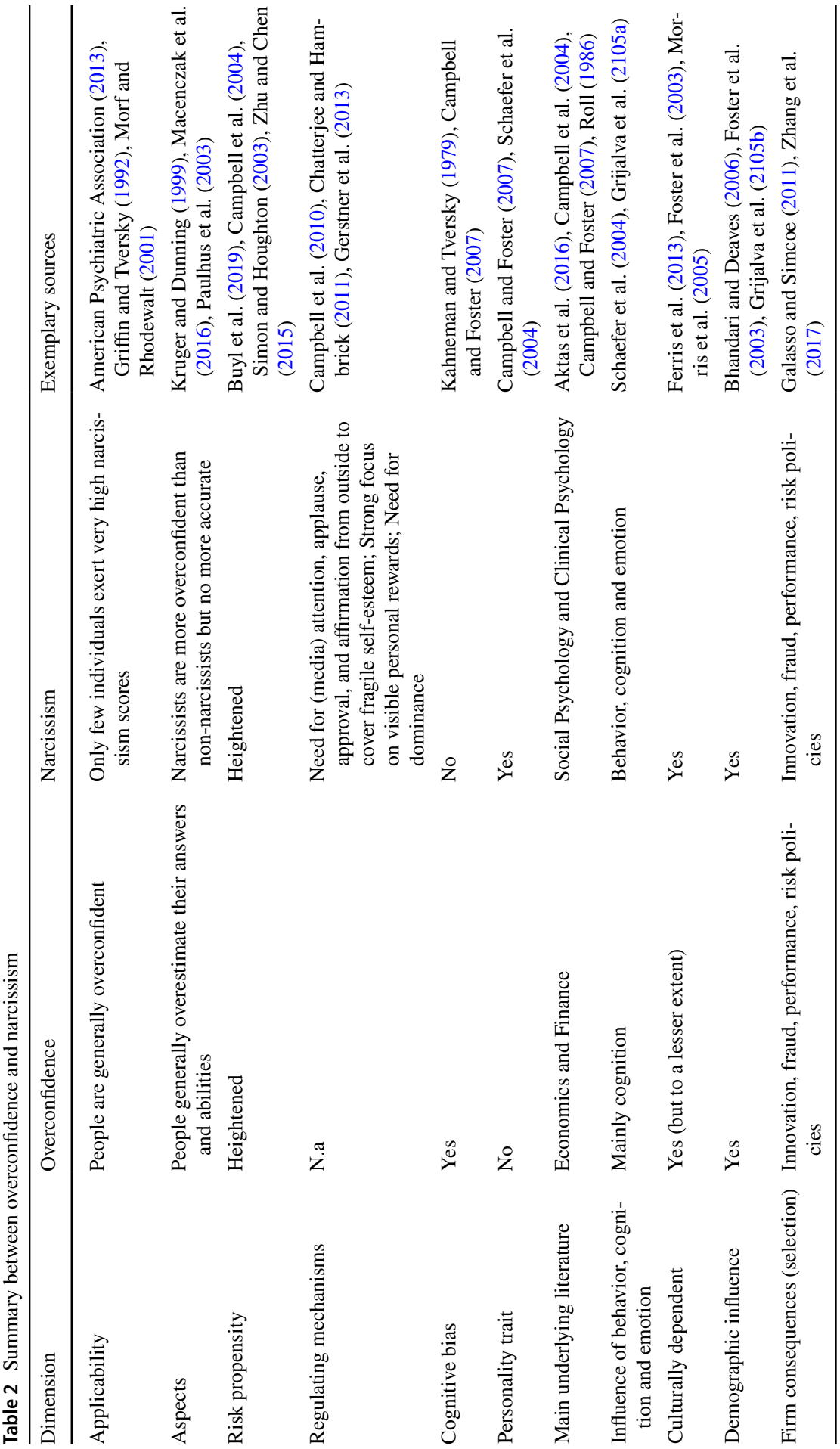




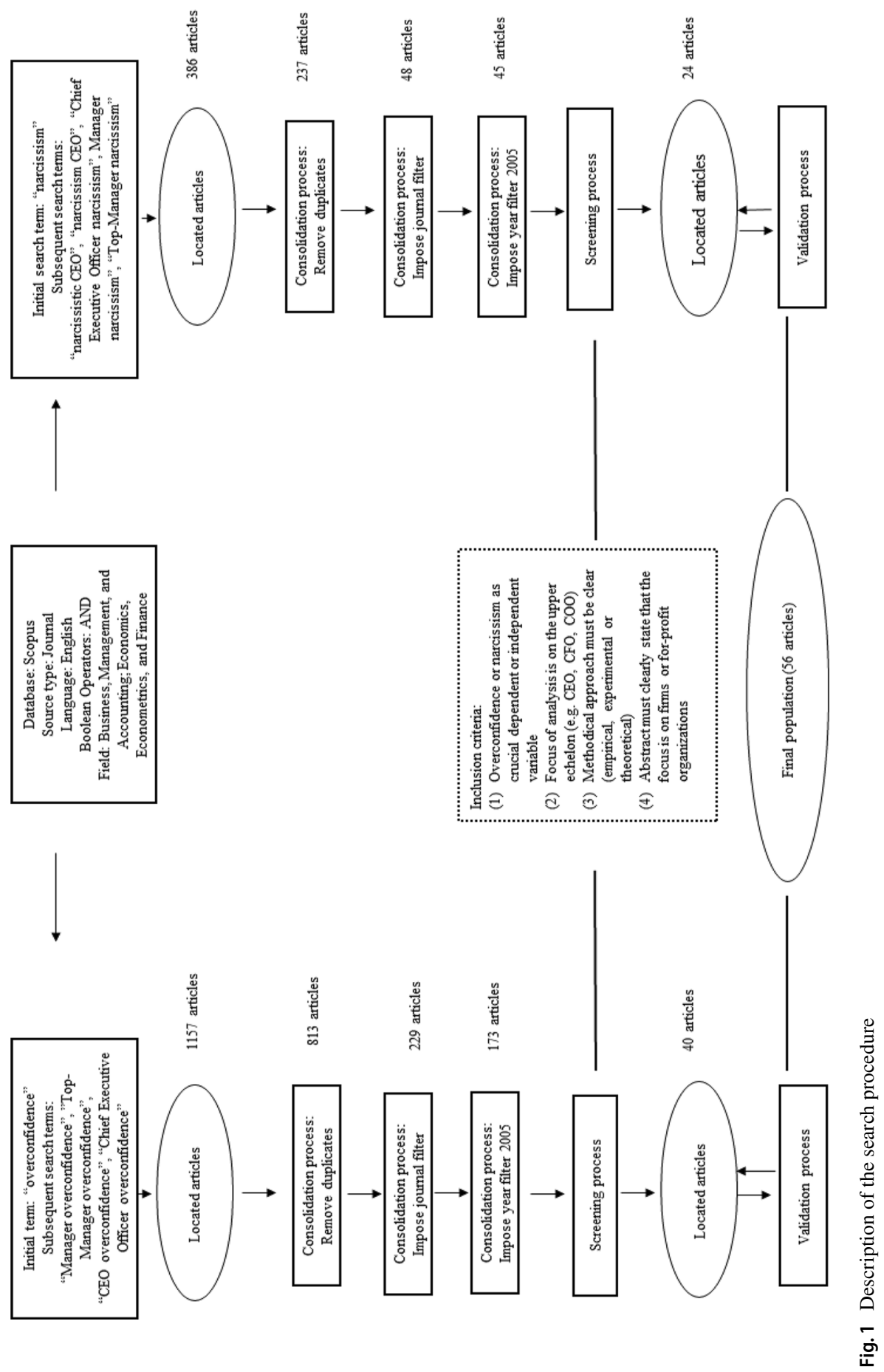


I restrict my approach to articles published in Scopus under the Business, Management, and Accounting and Economics, Econometrics, and Finance section because this allows theoretical and methodological heterogeneity but ensures that the articles are related to management and organizational studies. The raw search query lead to unique 1157 and 386 articles for overconfidence and narcissism, which were then analyzed and cleaned to exclude duplicates. This process lead to 813 and 237 articles. To impose quality restriction, I follow standard approaches of literature reviews (e.g., Brauer and Wiersema 2017) by only retaining leading journals in the review. The decision to focus only on a limited set is driven by the large amount of studies found in the first inductive step of the search procedure (1157 and 386) that is unfeasible to analyze and "quality" thresholds (Brauer and Wiersema 2017). Consequently, all $A+/ A$ (i.e., outstanding and leading international academic business research journals) journals of the German Association for Business Research (VHBJOURQUAL3) are included in the review. These are Academy of Management Journal, Academy of Management Review, Administrative Science Quarterly, Journal of International Business Studies, Journal of Management, Journal of Management Studies, Management Science, Organization Science, Organization Studies, Strategic Management Journal, American Economic Review, Journal of Finance, Journal of Applied Psychology, Journal of Accounting Research, Quarterly Journal of Economics, to name a few. ${ }^{2,3}$ Following this approach, I can rely on an external provided list of journals while ensuring heterogeneity in journal scope. For instance, the list includes core management outlets (e.g., Journal of Management) while also including applied management outlets engaged in psychological research (e.g., Journal of Applied Psychology, Personnel Psychology). Practitioner orientated journals (e.g., Harvard Business Review) are not eligible for the review as they not appear on the externally provided list. This threshold leads to 229 (overconfidence) and 48 (narcissism) articles.

As a next step to further distill the number of articles, I impose in the following that an articles must be published after 2004. The timeframe of 12 years (2005-2017) is large enough to detect shift in trends yet restricts the number of eligible articles. 2005 has been chosen because the bibliometric analysis reveals that Malmendier and Tate (2005) and Chatterjee and Hambrick (2007) are the most cited papers in the respective domains at the point of inquiry (Google Scholar: 2826 and 993).

This threshold leads to 173 (overconfidence) and 45 (narcissism) articles. As a next step, I impose four restrictions regarding scope and level of analysis of the selected papers:

\footnotetext{
${ }^{2}$ The VHB-JOURQUAL3 ranking is based upon surveys of members ("experts") covering several dimensions (e.g. review process, quality of articles etc.). Rankings in other countries show a very high overlap, in particular among top-journals. For instance, all A-ranked outlets can be also found on the Financial Times list 2016.

${ }^{3}$ The list with all journals can be found online: https://vhbonline.org/en/service/jourqual/vhb-jourqual-3/ complete-list-of-the-journals/
} 
1. Abstract must clearly state whether overconfidence or narcissism is a crucial dependent variable or crucial independent variable

2. Abstract must clearly state whether the focus of the analysis is on the upper echelon (e.g., CEO, CFO, COO)

3. Abstract must clearly state which methodological approach the article follows (e.g., empirical, experimental, theoretical)

4. Abstract must clearly state that the focus is on firms or for-profit organizations

I then double check my initial search (within search) list using search terms (including word stems) that are related to the level of analysis: chief executive officer overconfidence, ceo narcissism, ceo overconfidence, chief executive officer narcissism. The subsequent exclusion lead to 40 empirical overconfidence and 24 empirical narcissism articles. As a final step, the obtained articles were coded by two independent research assistants. The interrater reliability (IRR) was high on average with 88.44\% (overconfidence) and 85.56\% (narcissism). Remaining discrepancies were discussed until consensus was reached. Therefore, all included articles in this review were based on an iterative process. Articles that were not accessible or articles that did not pass the threshold after close reading were subsequently excluded. For instance, the article by Chen et al. (2014) passes the initial threshold as described above by reading the title, abstract and key words. However, closer reading (i.e., reading the paper beyond the abstract) reveals that overconfidence is a control variable for gambling preferences. These exclusions led to a final number of 56 papers. This number is comparable to previous approaches employing reviews in the management field (e.g., Köhn 2018, n=58; Parris and Peachey 2013, n=44). The overall detailed sample can be found in the online appendix. The analysis includes a deconstruction of the articles in important aspects of scholarly inquiry including sample size, level of analysis, dependent variable, and independent variable.

As a robustness test for the time and database choice, employing a simplified search string of "CEO AND narcissism" in the title, abstract and key word section of Scopus in July 2020 reveals that Petrenko et al. (2016), O'Reilly et al. (2014) and Zhu and Chen (2015) belong to the most cited papers in the database. Similarly, employing a simplified search string of "CEO AND overconfidence" in July 2020 reveals that Malmendier and Tate $(2005,2008)$ belong to the most cited paper. Since these papers are included, they indicate that the chosen time-frame captures central and important papers in the field. Another exploratory search on the database EBSCO was carried out, using the key words "CEO overconfidence" with the journal restrictions until 2018. It reveals that the work by Ferris et al. (2013), Chen et al. (2015) and Ho et al. (2016) are the most relevant articles to EBSCO. Similarly, a second exploratory search on the database EBSCO using the key words "CEO narcissism" with the time and journal restrictions reveals the work by Gerstner et al.(2013) and Zhu and Chen (2014) are the most relevant papers to EBSCO. Since these articles are included in the analysis, these results provide face-validity of the search procedure via Scopus. Finally, I check whether the deductive approach-based on theory-is correct to equate hubris and overconfidence. I employ a simplified search string in Scopus "CEO AND hubris" in July 2020, revealing that the most cited paper is Malmendier and Tate (2008), also including "hubris" and "overconfidence" in the keywords. As 


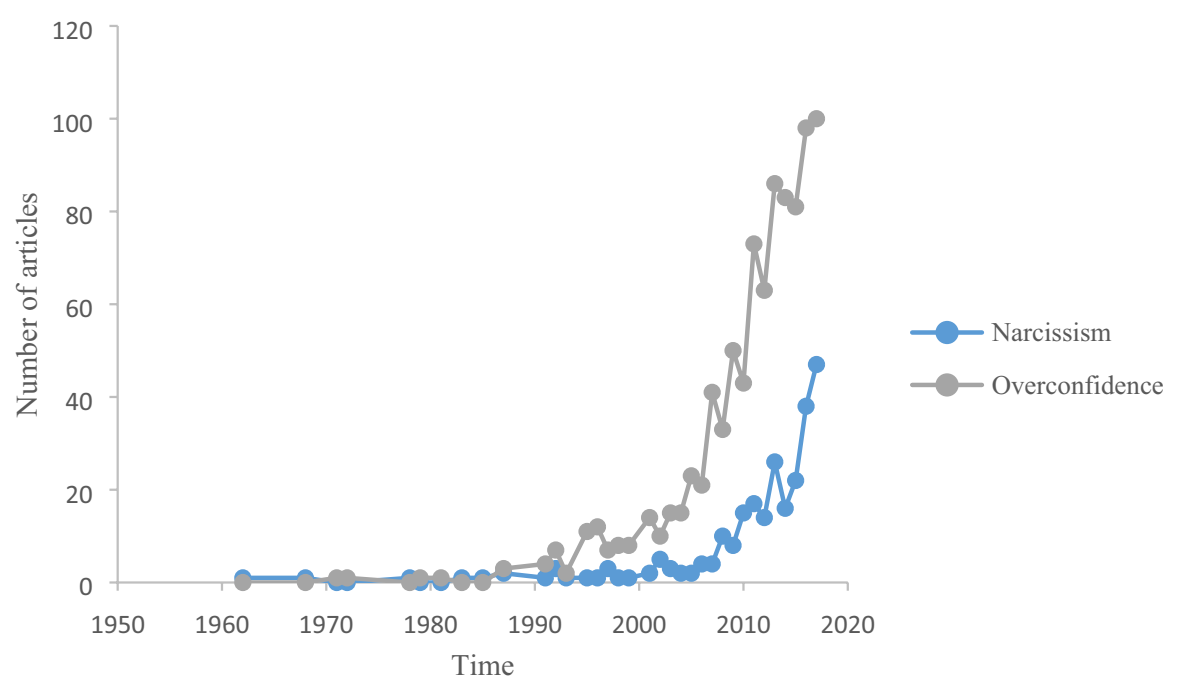

Fig. 2 Number of all overconfidence and narcissism articles in subject areas "econ" and "busi" until 2018

the paper is included, the inductive results provide some evidence that having a narrow search string captures central and important papers.

\section{Results}

\subsection{Descriptive results}

The search process revealed a sharp increase of interest over time. Approximately five times more articles about overconfidence and approximately eleven times more articles about narcissism in 2005-2017 compared to 1993-2005 appeared in the subject domains.

The results indicate that the narcissism construct has attracted greatest attention from large leadership journals (Leadership Quarterly, Journal of Business Ethics, Human Relations) as well as major journals in management (Journal of Management, Strategic Management Journal, Academy of Management Journal). At the same time, the construct appears in practitioner journals (Harvard Business Review, Business Horizons) indicating that it is of interest to a wide audience of academics and practice. Journal of Business Ethics (10.12\%) published the most articles followed by Leadership Quarterly (4.22\%).

In contrast, $\mathrm{CEO}$ overconfidence attracted most attention from major economic journals (Journal of Finance, Journal of Financial Economics, Review of Financial Studies) as well as-to a lower extent from management journals (Strategic Management Journal, Journal of Business Ethics). It also attracted attention from practitioner-orientated journals such as Long Range Planning. Organizational Behavior and Human Decision Processes (5.92\%) published the most articles followed by 


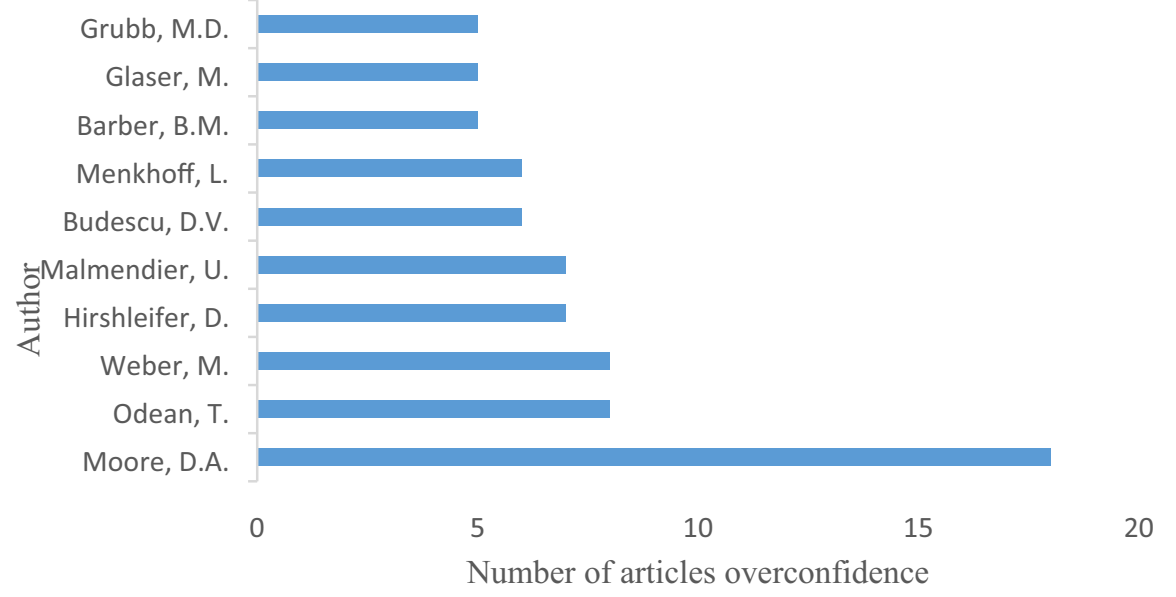

Fig. 3 Top 10 authors of overconfidence in subject areas "econ" and "busi" until 2018

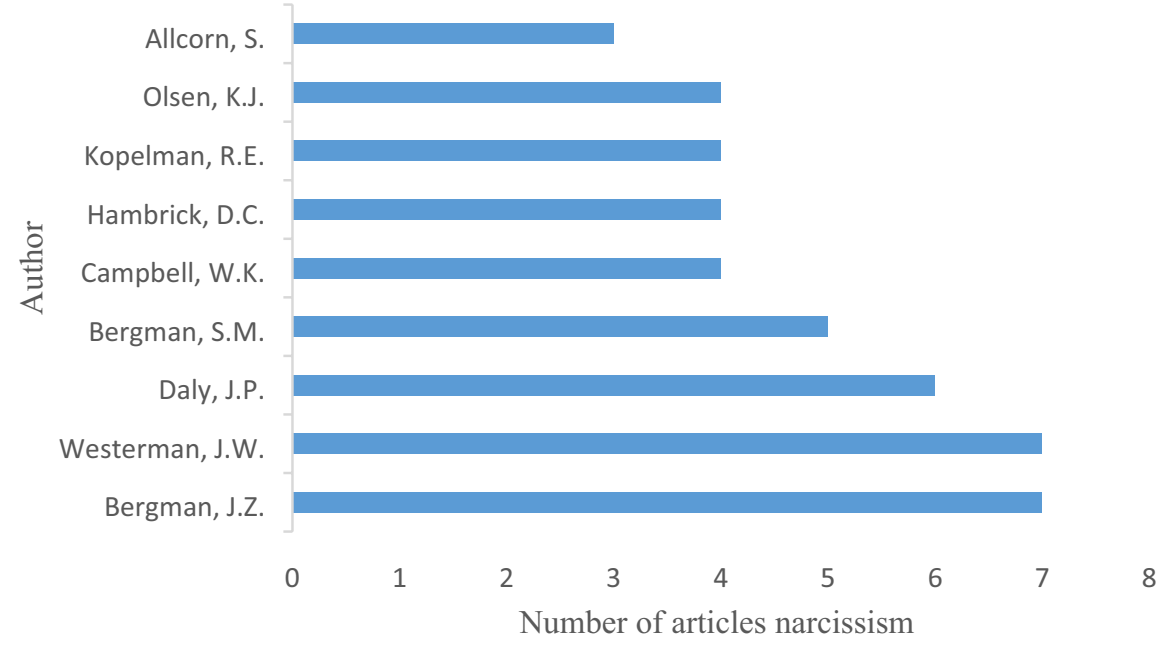

Fig. 4 Top 10 authors of narcissism in subject areas "econ" and "busi" until 2018

the Journal of Behavioral Decision Making (3.58\%). Generally, the field appears to be more dispersed than the narcissism construct. Figure 2 shows the number of studies of overconfidence and narcissism across fields. Figures 3 and 4 shows the Top-10 authors of overconfidence and narcissism research. Figure 2 indicates a rising interest in both overconfidence and narcissism in the last years since first papers appeared in the 1960s in the domain "economics, ecometrics and finance" and "business, management and accounting". For narcissism this is particularly true for the time since 2008 and for overconfidence since 2007. Figure 3 indicates that overconfidence is dominated by Finance and Economics scholar such as Moore, Odean 
and Hirshleifer. Narcissism (Fig. 4) appears to be more heterogeneous, with Psychology scholars such as Campbell and Management scholars such as Hambrick at the forefront. This reflects previous research depicting management research as able to attract perspectives more multiple disciplines (Nag et al. 2007).

\subsection{Detailed findings and organizational consequences}

Of the 56 articles in the final sample, all articles used variables hereinafter labeled as Innovation, M\&A, R\&D, Performance, Attention, Fraud, Risk, Entrepreneurial Orientation, Selection, Tenure, Pay, Risk, Market Reaction, Forecast or Cultural Disposition as outcomes of CEO overconfidence and CEO narcissism. Although overlapping to some extent, these dimensions are intended to summarize the main findings and reoccurring themes of the literature. The main findings are displayed in Table 3. Therefore, it allows a clear and organized identification of themes and organizational outcomes (e.g., Dixon-Woods et al. 2005). A synthesis and a more detailed view on the operationalization and method aspects of the papers can be found in the subsequent discussion. Therefore, researchers can identify research gaps with reference to methods, theories and constructs based on the compiled information while also providing an integrative framework (Paul and Criado 2020).

\subsection{Operationalization overconfidence}

Although empirical, anecdotal, and theoretical evidence exists stating that overconfidence and narcissism are closely related, there are profound differences on how these constructs are operationalized. It is beyond the scope of the paper to analyze the underlying reasons, the results may reflect higher-order differences in the socialization among and across disciplines.

The results suggests that the overconfidence constructs are dominantly based on Malmendier and Tate (2005) and that subsequent papers build on these approaches. Consequently, authors such as Hirshleifer et al. (2012) and McCarthy et al. (2017) tend to adapt these measures due to data constrains but retain its core intuition. Furthermore, the dominant usage of this measurement indicates a need to use unobtrusive measures because of the well-known social desirability issue and a potential lack of high response rates from top-decision makers necessary to construct time-series, large-scale econometric data sets. Additionally, these unobtrusive measurements provide enhanced data availability across contexts and time and do not suffer from interviewer bias (Hill et al. 2013). Therefore, it is of great importance to review the initial constructs.

Malmendier and Tate (2005) exploit the stock trading and stock option-exercising behavior as proxies for manager's inability to diversify their portfolio and constantly assuming a better than average effect. They construct two dummy variables Holder67 and Longholder for unexercised stock option behavior of CEOs and one dummy variable for stock trading behavior, Net Buyer. Holder67 describes CEOs that fail to exercise their stock option at least twice despite being 


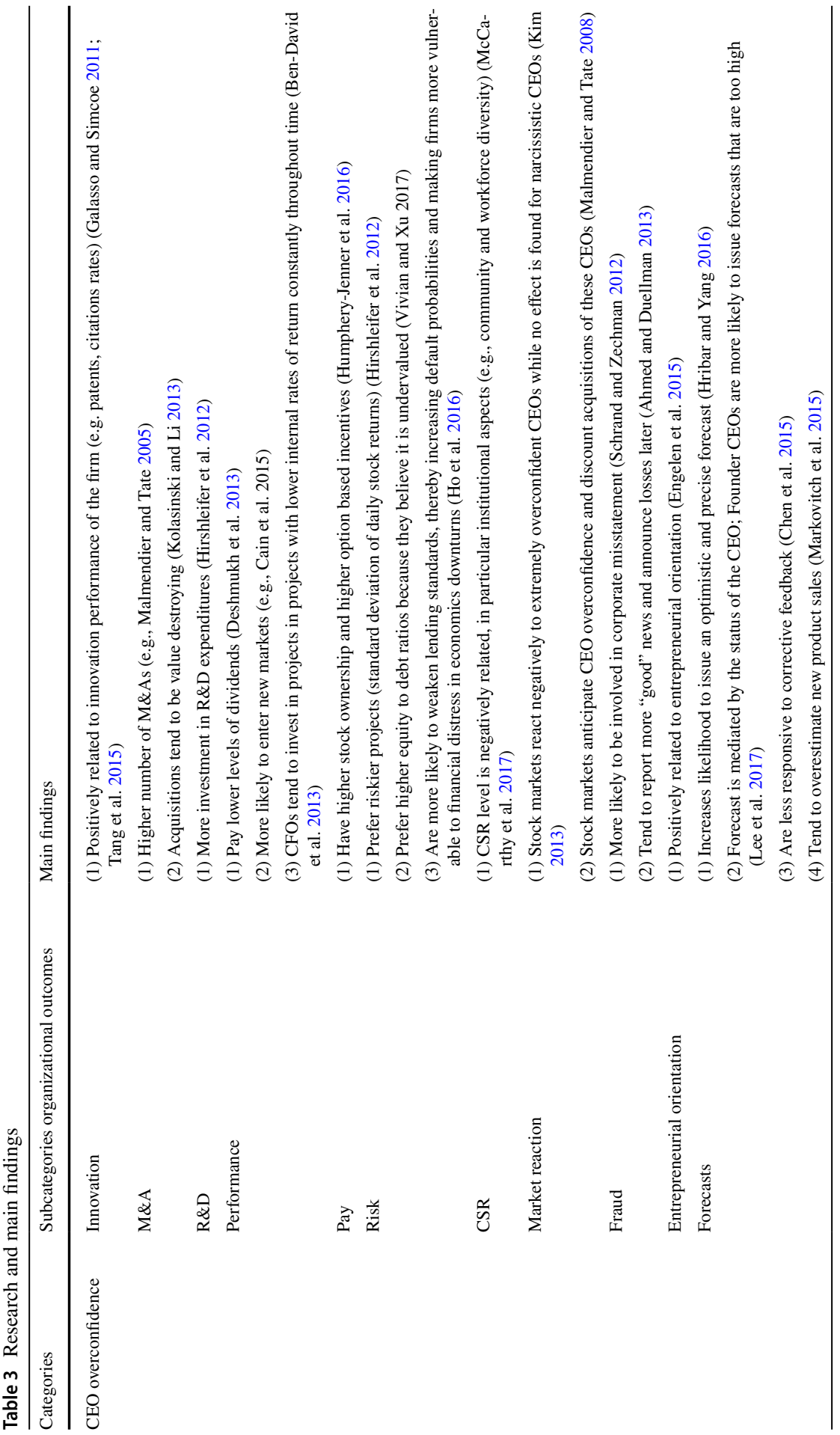




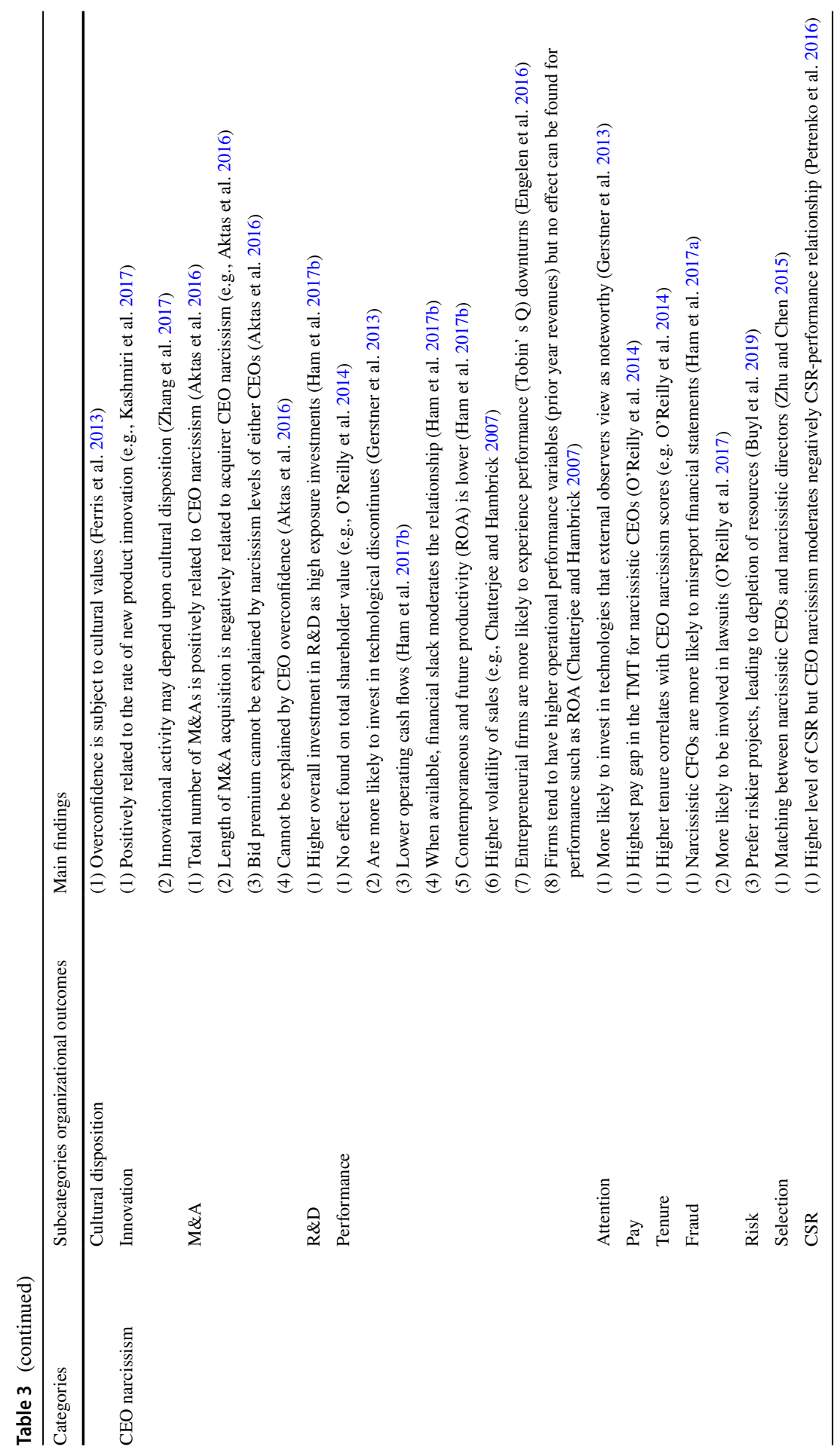


"in the money" by $67 \%$ (i.e., the stock option exceed its current market value) during the fifth year. This behavior is sought to capture the time-invariant behavior of CEOs. The authors control for different thresholds starting from 50 to $150 \%$ of "moneyness". Longholder classifies CEOs as overconfident if they fail to exercise stock options until the last year of its duration for at least 5 years to capture CEO's believe that the market systemically undervalues their performance. They find that $85 \%$ of managers classified as Longholder are also "in the money". Finally, Net Buyer classifies CEOs as overconfident if the sum of purchased company stocks exceeds the sum of sold company stocks during their first 5 years of tenure. Malmendier and Tate (2008) adopt the Longholder variable and add an outsider perspective to CEO overconfidence. They classify CEOs as overconfident if the number of articles per year for the respective CEO in media outlets (including The New York Times or The Economist etc.) associated with "confident" and "optimistic" articles exceeds the number of non-confident articles (e.g., frugal, steady). They find a high correlation among the media based indicators and stock option behavior. Malmendier et al. (2011) use Longholder, Holder67 and the media based operationalization to exploit early life exposures of CEOs (great depression; military service) to relate these measures to firm financing decisions. Furthermore, they use Pre- and Post-holder variables to distinguish between years before and after the Longholder behavior. Hribar and Yang (2016) adopt both Holder67 and media based measures of CEO overconfidence to relate it to management forecasts.

Using the term overoptimism, a sub-trait of overconfidence, Campbell et al. (2011) build on Malmendier and Tate $(2005,2008)$ and extend the given Holder67 measurement to CEOs that are by $100 \%$ "in the money" (excessively overconfident) and less than 30\% "in the money" respectively (underconfident). Therefore, they are interested in the differences between varying levels of overconfidence. They obtain the average price of the options ("moneyness") exercised by the CEOs because they do not have data concerning the specific exercising date.

Hirshleifer et al. (2012) use the Holder67 variable from Malmendier and Tate (2005) variable to link CEO overconfidence and firm innovation. Due to data constraints of the exact exercise date for each stock option, the authors calculate the average "in the money" factor of CEO's stock options per year to obtain their dichotomous variable. The authors also use the press based confidence variable by dividing the confidence articles (e.g. appearing in Fortune, Forbes, The Wall Street Journal) by non-confidence articles. Based solely on the Holder67 variable, Galasso and Simcoe (2011) identify overconfident CEOs to construct their CEO overconfidence and innovation study. In their study about dividend policy and CEO overconfidence, Deshmukh et al. (2013) adapt the Longholder variable as well as the media based variable. Banerjee et al. (2015) use the Holder variable and a subsequent dummy to capture whether an overconfident CEO is in the top quartile of overconfidence, as well as the media based variable. Engelen et al. (2015) use the average moneyness calculation of CEO stock options similar to aforementioned studies to analyze the relationship between CEO overconfidence and entrepreneurial orientation. Similarly, for their study of CSR and overconfidence, McCarthy et al. (2017) employ Holder67 by calculating the average "moneyness" of CEO stock options, similar to 
previous studies (Hirshleifer et al. 2012). Also due to data limitations, Kolasinski and Li (2013) use a similar approach by examining CEOs who buy own company stocks but lose money in the subsequent trade.

These results indicate the dominance of large-scale financial metrics to proxy CEO confidence. The results also suggests, however, that a few alternative approaches exist on how to operationalize and gather data on overconfidence.

For instance, using the term miscalibration or overprecision, a sub-form of overconfidence, Ben-David et al. (2013) survey CFOs of the S\&P 500 to examine the CFOs confidence interval about future stock market performance of the S\&P. Similarly, examining a variety of CEO characteristics such as optimism, Graham et al. (2013) survey via various channels several thousand CEOs and CFOs. Tang et al. (2015) examines overprecision via surveys comparing the forecasts of earning of large US companies in high-tech industries to their actual performance. Kim (2013) construct their "self-referencing measure" from CEO interview transcripts from CNBC by dividing the number of causal self-referencing items by the number of words by the CEO in the interview. Kallunki and Pyykkö (2013) examine CEO's and director's personal payment defaults in Finland to relate their measurement to financial distress of the firm. Drawing on linguistic cues during verbal and written speech, Lee et al. (2017) examine the tone of tweets of CEOs and the tone of speech of CEOs during conference calls. Hilary and Hsu (2011) use the difference between past earnings prediction and subsequent forecasts, while Hilary, Hsu et al. (2016) use "in the money stock options" in conjunction with textual analysis of firm press releases. Not relying on unobtrusive measures, Shipman and Mumford (2011) gather undergraduates' experimental paper-pen response to an ambiguously defined leadership scenario. Similarly, Markovitch et al. (2015) use MBA students in an experimental game to determine whether overconfidence predicts new product offerings.

The results regarding overconfidence indicate that dominant paradigms à la Malmendier and Tate (2005) can be found in the literature. Many studies have utilized personal stock option behavior by CEOs to proxy for overconfidence, indicating that financial measure by the authors depicts a state of the art operationalization in the literature to measure overconfidence. Whereas only a few studies directly assess overconfidence, these studies utilize student samples (e.g. Markovitch et al. 2015) with well-known validity concerns of these samples (Sears 1986). Despite its resource intensive character and the well know reluctance of TMT-members to answer sensitive topics, a few studies commenced to explore the overconfidence construct with actual TMT-cohorts (Ben-David et al. 2013). This direct assessment seems applaudable given the complexity of the construct (see Moore and Healy 2008). Furthermore, it may yield favorable results to circumvent content validity problems regarding unobtrusive measures of overconfidence.

An avenue for further research might be to pursue validation processes of the overconfidence measures. It remains unclear whether overconfidence is attributable to idiosyncratic firm, industry or manager characterizes. For instance, the dominant measure of option exercise behavior might be driven by personal wealth planning while commonly used outcome organizational variables might be driven by industry concentration. 


\subsection{Operationalization narcissism}

The results regarding narcissism indicate that Chatterjee and Hambrick's (2007) operationalization can be seen as a dominant paradigm in the literature. The authors use unobtrusive measures in a variety of company interactions with its environment (e.g., annual reports, interviews, press releases) to detect narcissistic CEOs. They code the CEO's photograph in the annual report, the CEO's prominence in the companies' press releases, the use of first person singular pronouns in interviews, and the CEO's compensation gap to the second highest paid executive. The authors aggregate the results. The authors also provide validity tests by security analysts that show the appropriateness of the measures. Chatterjee and Hambrick (2011) and Gerstner et al. (2013) use the same framework to capture how narcissistic executives respond to social cues and to the adoption of technological discontinuities in biotech. Similarly, authors such as Buyl et al. (2019) adapt this measurement and complement the validity of the construct by using linguistic traces of the CEO in the Letters to Shareholders. Patel and Cooper (2014) adapt Chatterjee and Hambrick's (2007) measurement and further validate the construct by stock analysts and clinical psychology researchers in their study of narcissistic CEOs. Zhu and Chen (2014, 2015) use the Chatterjee and Hambrick (2007) measurement to construct a narcissism score but provide additional validity tests in a subsample of video face-to-face interviews that were coded by two psychologists. Engelen et al. (2016) use the Chatterjee and Hambrick (2007) framework but exclude, due to data limitations, the first person singular count in interviews. Finally, in their test of innovative firm level activities in large, public U.S. firms, Kashmiri et al. (2017) also use the Chatterjee and Hambrick (2007) framework.

As their sole indicator of CEO narcissism of acquiring and target CEOs in the M\&A process, Aktas et al. (2016) use the ratio of total first-person pronouns in interview transcripts mainly from conference calls such as quarterly calls or industry specific calls. As a different yet unobtrusive measure, Petrenko et al. (2016) obtain publicly available videos and rate them based on the NPI. They additionally use the Chatterjee and Hambrick (2007) framework and find high and significant correlations between the media based measures (video) and the Chatterjee and Hambrick (2007) framework. In a different vein, Ham et al. (2017a, b) examine experimentally the relationship between the size of signature of participants and the NPI-score. Having provided evidence through an experimental setting, they use the size of CFO signatures in SEC filings for the narcissism construct.

Although unobtrusive measures of narcissism seem to be dominant, a few studies use direct measurements. For instance, Wales et al. (2013) employ the NPIquestionnaire to examine entrepreneurial orientation of 1525 young (i.e., less than 10 years) and small (10-250 employees) high-tech manufacturing firms. However, the small response rate $(14.35 \%$; 173 firms $)$ compared to the average response rate of academic business studies (mean = 55.6, S.D. $=19.7$; Baruch 1999) indicates that this method seems to be only adequate for small, cross-sectional samples.

O'Reilly et al. (2014) use internal assessments of co-workers of the CEO to determine, based on the NPI, his/her level of narcissism and further validate their measure by using textual analysis of the Letters to Shareholders. They find that the ratings are highly correlated. Similarly, using a questionnaire based on the NPI forwarded to company employees (third-party rating of the CEO), O'Reilly et al. (2017) examine 
the probability to be involved in a lawsuit. The authors further validate the measure by examining the number of first-person pronouns in the Letter to Shareholders. Again, this method seems to be appropriate with small sample sizes $(n=32)$. They find that their narcissism construct is positively correlated with CEO's use of first person singular pronouns in the cross-sectional setting and with his/her size of signature. Finally, Peterson et al. (2012) use direct, obtrusive measures (NPI) of 125 CEOs of small-medium-sized enterprises in high-technology. Similarly, Zhang et al. (2017) use the NPI to survey a random sample of Chinese firms with 206 CEOs.

Taken together, the review suggests that considerable heterogeneity among approaches exists. One dominant approach is to use unobtrusive measures for largescale and time-series data involving public companies. The paper by Chatterjee and Hambrick (2007) can be seen as a central paper in the paradigm to employ unobtrusive measures, also because it was cited by most follow-up studies. The paper also provides a blueprint for researchers wishing to employ unobtrusive measures in the field of narcissism. In contrast, a few studies use direct obtrusive measures because of different unit of analyses (e.g., small-medium-sized companies) or the use of (student) samples in experimental settings.

\section{Discussion and recommendations for further research}

\subsection{A synthesis of overconfidence and narcissism on organizational outcomes}

Based on the theoretically proposed distinct conceptualizations of overconfidence and narcissism, the systematic review confirms overlapping yet distinct consequences for organizational outcomes.

On the one hand, as provided as an overview in Table 3, research finds that both narcissism and overconfidence can have positive implication for firm level innovation, at least on easy-to measure innovation outcomes such as patent counts and the number of new product innovation (Galasso and Simcoe 2011; Kashmiri et al. 2017). The results may yet again confirm differential behavioral attributes of both constructs. In a new market, narcissistic CEOs may be better to speed up the innovation process, conquering new markets quickly by increasing the pace and speed of new product introductions. In contrast, patents underlie lengthy formal examination of the underlying technology or product, thereby raising the question whether product innovation rates are sustainable long-term proxies of firm innovation. In addition, Kashmiri et al. (2017) also finds that CEO narcissism is related to a product-harm-crisis. Regarding M\&As, CEO narcissism is related positively to the length of M\&A acquisition (Aktas et al. 2016), while overconfident CEOs conduct an overall higher number of M\&As compared to non-overconfident CEOs (e.g. Malmendier and Tate 2005). Interestingly, the overall number of M\&As is not significantly related to CEO narcissism (Chatterjee and Hambrick 2007). This indicates again different behavioral underpinnings of the CEO overconfidence and CEO narcissism construct. Narcissistic CEO need to dominate and dominate the decision making process in the M\&A, thereby leading to quick decisions regarding M\&As while there is general tendency of overconfident CEOs to conduct more M\&As. 
Another similar outcome of both CEO narcissism and overconfidence is that both constructs increase entrepreneurial orientation of the firm (Engelen et al. 2016; Wales et al. 2013). Narcissistic CEOs prefer riskier projects, leading to depletion of resources (Buyl et al. 2019) and overconfident CEOs also prefer riskier projects (Hirshleifer et al. 2012). Finally, overconfident CEOs are likely to be involved in corporate misstatement (Schrand and Zechman 2012) and they tend to report more "good" news and announce losses later (Ahmed and Duellman 2013). Similar to overconfidence, narcissistic CFOs are more likely to misreport financial statements (Ham et al. 2017a) and narcissistic CEOs are more likely to be involved in lawsuits (O'Reilly et al. 2017). Although it remains debatable how fraud can be conceptualized, both overconfident and narcissistic CEOs are more likely to be involved in ethically and legally questionable behavior.

On the other hand, overconfidence and narcissism predict very different sets of outcomes or a similar set of outcomes via different channels. CEO narcissism is linked with a higher overall investment in $R \& D$, while CEO overconfidence predicts higher capital expenditures but not R\&D or M\&A expenditures (Ham et al. 2017b). This indicates that $R \& D$ is particularly under the discretion of CEOs and that narcissistic CEOs see avenues such as R\&D to enhance their status and reputation via these channels. As a highly visible and attributable action, $\mathrm{R} \& \mathrm{D}$ spending is an ideal means for narcissistic CEOs to exert influence that overconfident CEOs per se do not undertake. Regarding performance, overconfident pay lower levels of dividends (Deshmukh et al. 2013) but predict higher absolute firm performance as measured by Return on Assets (ROA) and operating cash flow (Ham et al. 2017b). In contrast, most studies find that narcissistic CEOs have neutral or negative implications for overall performance. Chatterjee and Hambrick (2007) do find positive effects on operational metrics such as revenues but no effect on lagged performance such as ROA, while O' Reilly et al. (2014) find no effect on total shareholder value. In other words, narcissistic CEOs tend to inflate ratios that are under their discretion and that are primarily short term based such as revenues, but deplete resources in the long-term.

Gerstner et al. (2013) find that narcissistic CEOs are more likely to invest in technological discontinues. Patel and Cooper (2014) find that abnormal returns are higher at the onset of the crisis but lower in the post-crisis phase. In other words, narcissistic CEOs appear to have positive effects within the crisis with their need to dominate and initiate fast decision making but this is not sustainable. With their need for reinforcement, they invest in technologies not too much as overconfident CEOs may do, but they invest in technologies that they anticipate to be perceived by external parties as groundbreaking and noteworthy. Therefore, these CEOs tend to be more susceptible to selection errors because they want to be perceived as grandiose and noteworthy to cover up their fragile self-esteem. The characteristic of the outcome (e.g., noteworthiness, visibility) also seem to differentiate the relationship between overconfidence narcissism and CSR. While 
no relationship between CSR and overconfidence can be found (McCarthy et al. 2017), narcissistic CEOs may use CSR particularly to enhance their reputation (Petrenko et al. 2016) and therefore may overspend in these particular activities.

Finally, the results indicate differential effects of overconfidence and narcissism regarding CEO pay. Overconfident CEOs believe they can beat the odds, so they choose higher stock ownership and higher option based incentives for themselves (Humphery-Jenner et al. 2016). In contrast, no relationship between overall short and long-term pay and CEO narcissism can be found (Petrenko et al. 2016). Interestingly, CEO narcissism affects the absolute pay only in conjunction with tenure (O'Reilly et al. 2014). However, CEO narcissism affects the relative pay to the next highest team member, indicating the highest pay gap in the team for narcissistic CEOs (O'Reilly et al. 2014). This sense of entitlement and dominance in form of visible recognition of their status via compensation is a very different regulating mechanism than overconfident CEOs who simply believe they can personally beat the odds.

After having provided a synthesis of overlapping and differentiating mechanisms and consequences, I now proceed to a discussion and recommendation of the literature.

\subsection{Construct definitions}

Clear, precise and segregated construct definitions are crucial for theory building and subsequent empirical tests. However, research has employed, for instance, first-person singular pronouns in executive language use both for overconfidence and narcissism constructs. For instance, in their study of executive overconfidence and financial misreporting, Schrand and Zechman (2012) define overconfidence as an extreme form of narcissism. Thus the authors employ unobtrusive narcissism constructs developed by Chatterjee and Hambrick (2007), thereby treating overconfidence and narcissism as equivalent. Kim (2013) treats the overconfidence construct similarly. If borrowing operationalization from other research streams, research should be concise and explicit about the construct of interest based on theoretical reasoning. This is important because a clear theoretical conceptualizations spills over to the empirics. For instance, a clear definition with distinguishable dimensions of a construct is a prerequisite to employ unobtrusive measures (Chatterjee and Hambrick 2007). A clear theoretical definition is also important to theorize and empirically check the independent and combined effects of overconfidence and narcissism. I argue in this review that both constructs are linked and correlated but theoretically distinct. One does not need to be narcissistic to be overconfident and vice versa, but this could be the case.

\subsection{Interdependence of constructs}

The analysis reveals that no paper explicitly links CEO overconfidence and CEO narcissism, thereby providing avenues for further research. However, it is applaudable 
that papers started to recognize the link between overconfidence and narcissism implicitly. For instance, Aktas et al. (2016) and Ham et al. (2017a, b) control in their narcissism studies for the possibility of overconfidence. However Ham et al. (2017b) do not find a significant correlation between their narcissism and overconfidence measure, suggesting that these are distinct constructs. Research should control for the explicit presence of overconfidence and narcissism while being clear at the same time about the definitions and empirical distinctions. First studies in the general literature using hubris and narcissism suggest that examining on the nuanced firm level effects of CEO personality inclination may be a fruitful avenue for future research (Tang et al. 2018). Moreover, research should clearly elaborate on the level of examination yet needs to control for the interaction of sub-traits of narcissism (grandiose, vulnerable) and overconfidence (overplacement, miscalibration, and overoptimism).

\subsection{Pursuing validation of constructs}

Generally speaking, I find that narcissism and overconfidence rely greatly on unobtrusive measurements. Although these measures provide advantages in situations where interview or questionnaire responses might be difficult or impossible to obtain, it is important to consider the validity of unobtrusive constructs (see Hill et al. 2013). For instance, although single dimensions such as the usage of first person pronouns have attracted criticism regarding its validity of narcissism (Koch and Biemann 2014), several studies still rely on single dimension measurements (Aktas et al. 2016; Kim 2013). The usage of several constructs (that can be aggregated statistically) may mitigate validity concerns. However, research should be explicit whether the inclusion of additional dimensions sufficiently explains more variance and how these additional dimensions relate to theory. For instance, Rijsenbilt and Commandeur (2013) proposed 15 unobtrusive measures while Chatterjee and Hambrick (2007) considered only four variables. Similar concerns hold true for the overconfidence constructs. I find several studies that are based on single proxies of the focal construct (e.g., Ferris et al. 2013), making them more prone to measurement errors. As the content validity of the overconfidence construct has been questioned by authors (Hill et al. 2014), it is important to choose several unobtrusive measures that are grounded in theory. Content validity problems might be exacerbated if the overconfidence construct is solely based on a single variable. However, every unobtrusive measure should be derived based on theoretical reasoning and rigorously tested. For instance, a popular measurement is the media based operationalization as used by Malmendier and Tate (2008). However, these measures are based upon ex ante specified word lists to derive confidence and non-confidence categories and are then applied in a deductive manner, a form of content analysis (see Krippendorff 1980). They are ought to capture the underlying meaning of the linguistic phrase. It remains questionable, however, whether the identified linguistic traces of overconfidence (e.g. "confidence") or non-confidence (e.g. "frugalent") comprehensively covers overconfidence. Several 
authors, such as McKenny et al. (2013) and Gamache et al. (2015), provide guidance on how to generate and validate pre-specified word lists. Hence, research should be careful about the application of content analysis and its validation procedure.

On the side of convergent validity for the narcissism construct, several authors provide validity efforts by using rating of stock market experts, psychologists, or security analysts (e.g., Patel and Cooper 2014, Chatterjee and Hambrick 2007). This is important to isolate the construct of interest, to avoid large overlaps with other constructs and hence to rule out alternative explanations. For instance, unobtrusive measures captured in certain contexts (e.g. Email, Letters to Shareholders) might be related to environmental influences or company culture as opposed to micro levels of narcissism. Similarly for the overconfidence construct, the unobtrusive measure of CEO stock option exercise behavior as in Malmendier and Tate (2005) might be related to alternative explanations such as wealth planning of the CEO. Although research used multiple dimensions of the construct (e.g., stock option exercise behavior and media portrayal in conjunction), further convergent validity using subsamples could be reached by employing other qualitative methods (e.g. interviewing or surveying experts or CEOs). This may help to demonstrate that the unobtrusive measures captures the intended construct.

In addition, the main usage in narcissism research of rather narrow industries such as computer, software, manufacturing or banking (Buyl et al. 2019; Chatterjee and Hambrick 2007; Patel and Cooper 2014) and US-samples may diminish external validity. Therefore, research should try to demonstrate the effect in a broader range of industries and with non-US executive samples. By doing so, research needs to acknowledge that variance in the sample may stem from at least two sources: within industry variance and within firm variance. As the "true effect" of narcissism and overconfidence is muddled in the other effects, for instance industry, year, firm and individual level effects (e.g., Fitza 2014; Mackey 2008; McGahan and Porter 1997) and may change independently over time in longitudinal studies, research should explicitly address these possibilities. For instance, by using variance decomposition techniques.

\subsection{Level of analysis}

The dominant level of analysis is the CEO level. Only very few papers of narcissism and overconfidence research consider other members of the TMT such as Chief Financial Officers (Ben-David et al. 2013; Ham et al. 2017a). Future studies could elaborate on this and examine on the interplay of personality characteristics of several members of the TMT. For instance, do overconfident (or narcissistic) CEOs "accept" other less overconfident (i.e., humble) members of the TMT or do they seek to bond with similar executives (i.e., homophily)? Furthermore, on a firm level, most studies deal with very large and public firms. It would be therefore interesting to examine the effect of CEO personality dispositions in smaller firms. For instance, 
do CEOs in smaller firms exert higher or lower levels of narcissism? What conditional factors may explain deviating results?

\subsection{Considering endogeneity and self-selection}

The endogenous nature of many firm level dependent variables (e.g. performance) is an important problem in organizational research (e.g., Hamilton and Biemann 2003). Commonly used strategies such as lagged independent variables might not always be sufficient. A few papers incorporate exogenous variation (e.g., Ho et al. 2016; Patel and Cooper 2014; Buyl et al. 2019) to mitigate these concerns and to apply standard econometrics techniques such as two stage least squares (2SLS). In particular, narcissism research, that is located in the management field, may further utilize methodologies from other fields. This may include two-stage least squares techniques, differencein-difference estimations or propensity score matching that are frequently employed in economic journals. Regarding the research design, Banerjee et al. (2015) and Ho et al. (2016) provide good examples on how to utilize exogenous changes. Banerjee et al. (2015) exploit changes in Sarbanes Oxley-act legislation while Ho et al. (2016) exploit exogenous macroeconomic shocks due to the financial crisis. Although it not easy to obtain exogenous variations or instrumental variables, both research streams should actively pursue these approaches to strengthen inference made from non-experimental data. Moreover, given that overconfident and narcissistic individuals are more likely to be elected as leaders (self-selection) (e.g., Nevicka et al. 2011), considering the endogenous nature is particularly important. Table 4 in the Appendix provides a stylistic overview about strategies to cope with Endogeneity.

\subsection{Considering mediators and moderators}

Although we know a variety of contextual variables such as the role of certain corporate governance practices (e.g., CEO stock option pay, block ownership, presence of independents directors; see Buyl et al. 2019), the role of CEO cognition (e.g., audience engagement; see Gerstner et al. 2013) or the size of the board (e.g., Kolasinski and Li 2013), it is poorly understood whether or how moderators or mediators are intertwined. Research should actively pursue other contextual variables that are important for the CEO overconfidence or CEO narcissism-firm level outcome relationship and elaborate on the interaction effects of these contextual variables.

\subsection{Inclusion of innovative data}

Entrepreneurship studies have long shown that innovative data sets such as Twitter data may enable researchers to circumvent low response rates and method biases (e.g., Fisch and Block 2020). In fact, a very current study (not included in the 
review) does show that Twitter data in sport contexts can be obtained to measures narcissism (Grijalva et al. 2019). As this kind of data can be seen as unobtrusive measure as well, researchers should adhere to best practice advice to show that the measure exhibits sufficient validity (content and convergence).

\subsection{Perception of overconfidence and narcissism}

Although market reaction incorporate CEO overconfidence and narcissism (Aktas et al. 2016; Malmendier and Tate 2008), research also indicates that both overconfidence and narcissism are societally accepted even if it is revealed (e.g., Kennedy et al. 2013). A sender-receiver model might be adequate to capture both the characteristics of the audience who receive the signal of the sender as well as the characteristic of the sender. This may also further provide evidence how the narcissistic or overconfident characteristics of the receiver shapes the perception of the narcissistic or overconfident sender.

\section{Limitations and conclusions}

\subsection{Limitations}

After having provided detailed effects and recommendation of CEO overconfidence and CEO narcissism, as with any study, limitations must be addressed. First, the article relies dominantly on one leading database, applies a journal threshold that is biased towards basic research, focuses on English speaking empirical articles as well as limits its time frame until 2018. Although subsequent analyses in a second database and with an updated time-frame suggests that the analysis includes the most relevant papers (e.g., most cited), future research may tackle these issues. These certainly strong thresholds were necessary to (a) reduce the overall high number of articles to a feasible number and to (b) bridge the disciplinary backgrounds of the two constructs. Future studies may tackle these selection biases by incorporating approaches that aim to depict and visualize the overall breadth of the field (e.g., bibliometric studies, Zupic and Čater 2015). The overall goal of the research was to provide a comprehensive and balanced perspective of the both constructs, thereby encountering many trade-offs and creative decisions that make review articles unique to other forms of research (Short 2009). I am confident that the analyzed literature and provided recommendations provide a fertile ground to be viewed, read, discussed, and debated in the management community.

Second, thematic analysis has been described in management as lacking transparency, lacking explicit procedures and aims, and providing little theoretical structure, therefore being subject to heightened subjectivity by the author (e.g., Dixon-Woods et al. 2005; Tranfield et al. 2003). As the audience of the study is a management 
audience, creative elements and a balanced perspective remain an important part of narrative reviews (Short 2009). In addition, the field appears to be dynamic in terms of outcomes variables, research approaches and the number of publications. However, future studies may employ bibliometric approaches or meta-analytical approaches to increase formal inquiry.

Third, the search string includes relatively narrow descriptions of the construct at hand. Based on theoretical reasoning, I neglect other forms and synonyms of overconfidence and narcissism. Although established and confirmed via the inductive search, future research could extend the constructs towards miscalibration (overconfidence), Machiavellianism (narcissism), or psychopathy (narcissism). However, researchers should be aware that this step needs theoretical motivation.

Fourth, the restrictive focus on organizational outcomes and members of the TMT may fall short to include abundant research in other fields, in particular, Psychology. Although it was the aim of the study to provide an overview about the studies relevant to a management audience only, research in Psychology emphasizes that narcissism and overconfidence are inherently complex and multifaceted constructs. Future research may focus on differential forms of overconfidence and narcissism (e.g., grandiose).

\subsection{Conclusions}

The purpose of the review was to relate research on overconfidence and narcissism from a diverse field of research traditions to organizational outcomes. Although I do not pretend to resolve debates whether overconfident or narcissistic CEOs are "born or made", discussing the current voluminous and heterogeneous literature on overconfidence and narcissism provides important insights. I find that both literature stream examine similar organizational outcomes yet differ in the employed methodologies. Moreover, I find that CEO overconfidence and CEO narcissism have been related to similar outcomes variables (including fraud, pay or organizational performance) but how they affect these outcomes depends on very different regulating mechanisms of overconfident and narcissistic CEOs. In addition, I find little interaction across research streams that may inhibit our understanding of two interrelated yet distinct constructs. These differences may reflect deeper diverging logics in Economics, Psychology, or Finance on how to conduct research that can be only be resolved by interdisciplinary research. Therefore, I recommend approaches on how these dispersed literature streams may benefit from each other.

Taken together, the review highlights state of the art research finding and outlines future research avenues. Therefore, the review contributes to a growing literature (e.g., 
Campbell et al. 2010; Resick et al. 2009) that goes beyond the notion of dark or bright executive personality traits as either "detrimental" or "beneficial" for organizational outcomes. While we know from idiosyncratic firm level observations how managers behave and impose their "style" on organizations (Drucker 1954; Mintzberg 1971), the systematic empirical inquiry of "dark" and "bright" CEO traits seems to be a fruitful avenue for further research. I encourage researchers to further validate unobtrusive measures and simultaneously, employ existing validated social-psychological scales to a representative cohort of actual decision makers, while also exploiting exogenous variation and longitude data sets. Moreover, with the rise of new, standardized and retrievable data (e.g., video, social media), the field will have access to a broader range of data to understand the behavior of actual top-executives and its influence of firm-level outcomes. This is important because CEO overconfidence and narcissism research are not just mere academic or "interesting" psychological constructs but shed light on the decision making processes of top-executives and their role in leadership, potentially enabling us to better understand real world phenomena such as financial crises.

Funding Open Access funding provided by Projekt DEAL.

\section{Compliance with ethical standards}

Conflict of interest The author declare that they have no conflict of interest.

Open Access This article is licensed under a Creative Commons Attribution 4.0 International License, which permits use, sharing, adaptation, distribution and reproduction in any medium or format, as long as you give appropriate credit to the original author(s) and the source, provide a link to the Creative Commons licence, and indicate if changes were made. The images or other third party material in this article are included in the article's Creative Commons licence, unless indicated otherwise in a credit line to the material. If material is not included in the article's Creative Commons licence and your intended use is not permitted by statutory regulation or exceeds the permitted use, you will need to obtain permission directly from the copyright holder. To view a copy of this licence, visit http://creativecommons.org/licen ses/by/4.0/.

\section{Appendix}

See Table 4. 


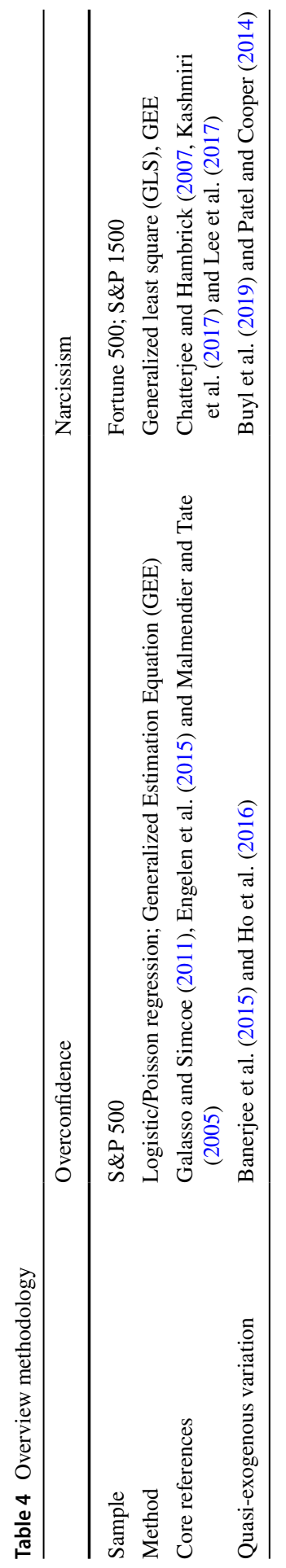




\section{References}

Ahmed A, Duellman S (2013) Managerial overconfidence and accounting conservatism. J Account Res 51(1):1-30. https://doi.org/10.1111/j.1475-679X.2012.00467.x

Aktas N, de Bodt E, Bollaert H, Roll R (2016) CEO narcissism and the takeover process: from private initiation to deal completion. J Financ Quant Anal 51(01):113-137. https://doi.org/10.1017/S0022 109016000065

Allio RJ (2007) Bad leaders: how they get that way and what to do about them. Strategy Leadersh 35(3):12-17. https://doi.org/10.1108/10878570710745785

American Psychiatric Association (2013) Diagnostic and statistical manual of mental disorders: DSM-5. American Psychiatric Association, Arlington

Bandiera O, Lemos R, Prat A, Sadun R (2013) Managing the family firm: evidence from CEOs at work. National Bureau of Economic Research, Cambridge

Banerjee S, Humphery-Jenner M, Nanda V (2015) Restraining overconfident CEOs through Improved governance: evidence from the sarbanes-oxley act. Rev Financ Stud 28(10):2812-2858. https://doi. org/10.1093/rfs/hhv034

Barber BM, Odean T (2001) Boys will be boys: gender, overconfidence, and common stock investment. Q J Econ 116(1):261-292. https://doi.org/10.1162/003355301556400

Baruch Y (1999) Response rate in academic studies-a comparative analysis. Hum Relat 52(4):421-438. https://doi.org/10.1177/001872679905200401

Ben-David I, Graham JR, Harvey CR (2013) Managerial miscalibration. Q J Econ 128(4):1547-1584. https://doi.org/10.1093/qje/qjt023

Bertrand M, Schoar A (2003) Managing with style: the effect of managers on firm policies. Q J Econ 118(4):1169-1208. https://doi.org/10.1162/003355303322552775

Bhandari G, Deaves R (2006) The demographics of overconfidence. J Behav Finance 7(1):5-11. https:// doi.org/10.1207/s15427579jpfm0701_2

Boddy CR (2011) The corporate psychopaths theory of the global financial crisis. J Bus Ethics 102(2):255-259. https://doi.org/10.1007/s10551-011-0810-4

Bogart LM, Benotsch EG, Pavlovic JDP (2004) Feeling superior but threatened: the relation of narcissism to social comparison. Basic Appl Soc Psychol 26(1):35-44. https://doi.org/10.1207/s1532 4834basp2601_4

Brauer M, Wiersema M (2017) Analyzing analyst research: a review of past coverage and recommendations for future research. J Manag 62(11):014920631773490. https://doi.org/10.1177/0149206317 734900

Brown AD (1997) Narcissism, identity, and legitimacy. Acad Manag Rev 22(3):643. https://doi. org/10.2307/259409

Busenbark JR, Krause R, Boivie S, Graffin SD (2016) Toward a configurational perspective on the CEO. J Manag 42(1):234-268. https://doi.org/10.1177/0149206315618448

Busenitz LW, Barney JB (1997) Differences between entrepreneurs and managers in large organizations: biases and heuristics in strategic decision-making. J Bus Ventur 12(1):9-30. https://doi. org/10.1016/S0883-9026(96)00003-1

Buyl T, Boone C, Wade JB (2019) CEO narcissism, risk-taking, and resilience: an empirical analysis in US commercial banks. J Manag 45(4):1372-1400

Caligor E, Levy KN, Yeomans FE (2015) Narcissistic personality disorder: diagnostic and clinical challenges. Am J Psychiatry 172(5):415-422. https://doi.org/10.1176/appi.ajp.2014.14060723

Camerer C, Lovallo D (1999) Overconfidence and excess entry: an experimental approach. Am Econ Rev 89(1):306-318. https://doi.org/10.1257/aer.89.1.306

Campbell KW, Foster JD (2007) The narcissistic self: background, an extended agency model, and ongoing controversies. In: Sedikides C, Spencer S (eds) The self. Psychology Press, New York, pp 115-138

Campbell WK, Miller JD (2011) The handbook of narcissism and narcissistic personality disorder. Wiley, Hoboken

Campbell WK, Rudich EA, Sedikides C (2002) Narcissism, self-esteem, and the positivity of self-views: two portraits of self-love. Personal Soc Psychol Bull 28(3):358-368. https://doi.org/10.1177/01461 67202286007

Campbell WK, Goodie AS, Foster JD (2004) Narcissism, confidence, and risk attitude. J Behav Decis Mak 17(4):297-311. https://doi.org/10.1002/bdm.475 
Campbell WK, Hoffman BJ, Campbell SM, Marchisio G (2010) Narcissism in organizational contexts. Hum Resour Manag Rev 1:1. https://doi.org/10.1016/j.hrmr.2010.10.007

Campbell TC, Gallmeyer M, Johnson SA, Rutherford J, Stanley BW (2011) CEO optimism and forced turnover. J Financ Econ 101(3):695-712. https://doi.org/10.1016/j.jfineco.2011.03.004

Carpenter MA, Geletkanycz MA, Sanders WG (2004) Upper echelons research revisited: antecedents, elements, and consequences of top management team composition. J Manag 30(6):749-778. https ://doi.org/10.1016/j.jm.2004.06.001

Chatterjee A, Hambrick DC (2007) It's all about me: narcissistic chief executive officers and their effects on company strategy and performance. Adm Sci Q 52(3):351-386. https://doi.org/10.2189/ asqu.52.3.351

Chatterjee A, Hambrick DC (2011) Executive personality, capability cues, and risk taking. Adm Sci Q 56(2):202-237. https://doi.org/10.1177/0001839211427534

Chatterjee A, Pollock TG (2017) Master of puppets: how narcissistic CEOs construct their professional worlds. Acad Manag Rev 42(4):703-725. https://doi.org/10.5465/amr.2015.0224

Chen S (2010) The role of ethical leadership versus institutional constraints: a simulation study of financial misreporting by CEOs. J Bus Ethics 93(S1):33-52. https://doi.org/10.1007/s10551-010-0625-8

Chen Y, Podolski EJ, Rhee SG, Veeraraghavan M (2014) Local gambling preferences and corporate innovative success. J Financ Quant Anal 49(01):77-106. https://doi.org/10.1017/S0022109014000246

Chen G, Crossland C, Luo S (2015) Making the same mistake all over again: CEO overconfidence and corporate resistance to corrective feedback. Strateg Manag J 36(10):1513-1535. https://doi. org/10.1002/smj.2291

Cho TS, Hambrick DC (2006) Attention as the mediator between top management team characteristics and strategic change: the case of airline deregulation. Organ Sci 17(4):453-469. https://doi. org/10.1287/orsc.1060.0192

Craig R, Amernic J (2011) Detecting linguistic traces of destructive narcissism at-a-distance in a CEO's letter to shareholders. J Bus Ethics 101(4):563-575. https://doi.org/10.1007/s10551-011-0738-8

de Vries MFRK, Miller D (1985) Narcissism and leadership: an object relations perspective. Hum Relat. https://doi.org/10.1177/001872678503800606

Deluga RJ (1997) Relationship among American presidential charismatic leadership, narcissism, and rated performance. Leadersh Q 8(1):49-65. https://doi.org/10.1016/S1048-9843(97)90030-8

Deshmukh S, Goel AM, Howe KM (2013) CEO overconfidence and dividend policy. J Financ 22(3):440463. https://doi.org/10.1016/j.jfi.2013.02.003

Dimaggio P, Powell WW (1983) The iron cage revisited: collective rationality and institutional isomorphism in organizational fields. Am Sociol Rev 48(2):147-160

Dixon-Woods M, Agarwal S, Jones D, Young B, Sutton A (2005) Synthesising qualitative and quantitative evidence: a review of possible methods. J Health Serv Res Policy 10(1):45-53. https://doi. org/10.1177/135581960501000110

Drucker PF (1954) The practice of management. Harper \& Row, New York

Emmons RA (1984) Factor analysis and construct validity of the narcissistic personality inventory. J Personal Assess 48(3):291-300. https://doi.org/10.1207/s15327752jpa4803_11

Emmons RA (1987) Narcissism: theory and measurement. J Personal Soc Psychol 52(1):11-17

Engelen A, Neumann C, Schwens C (2015) "Of course i can": the effect of CEO overconfidence on entrepreneurially oriented firms. Entrep Theory Pract 39(5):1137-1160. https://doi.org/10.1111/ etap.12099

Engelen A, Neumann C, Schmidt S (2016) Should entrepreneurially oriented firms have narcissistic CEOs? J Manag 42(3):698-721. https://doi.org/10.1177/0149206313495413

Fenichel O (1938) The drive to amass wealth. Psychoanal Q 7(1):69-95

Ferris SP, Jayaraman N, Sabherwal S (2013) CEO overconfidence and international merger and acquisition activity. J Financ Quant Anal 48(01):137-164. https://doi.org/10.1017/S0022109013000069

Finkelstein S, Hambrick DC (1990) Top-management-team tenure and organizational outcomes: the moderating role of managerial discretion. Adm Sci Q 35(3):484. https://doi.org/10.2307/2393314

Finkelstein S, Hambrick D, Cannella AA (2009) Strategic leadership: theory and research on executives, top management teams, and boards strategic management series. Oxford Univ. Press, Oxford

Fisch C, Block J (2018) Six tips for your (systematic) literature review in business and management research. Manag Rev Q 68(2):103-106. https://doi.org/10.1007/s11301-018-0142-X

Fisch C, Block JH (2020) How does entrepreneurial failure change an entrepreneur's digital identity? Evidence from Twitter data. J Bus Ventur. https://doi.org/10.1016/j.jbusvent.2020.106015 
Fitza MA (2014) The use of variance decomposition in the investigation of CEO effects: How large must the CEO effect be to rule out chance? Strateg Manag J 35(12):1839-1852. https://doi.org/10.1002/ smj. 2192

Forbes DP (2005) Are some entrepreneurs more overconfident than others? J Bus Ventur 20(5):623-640. https://doi.org/10.1016/j.jbusvent.2004.05.001

Foster JD, Keith Campbell W, Twenge JM (2003) Individual differences in narcissism: inflated self-views across the lifespan and around the world. J Res Personal 37(6):469-486. https://doi.org/10.1016/ S0092-6566(03)00026-6

Freud S (1914) On narcissism: an introduction. In: Strachey J et al (Trans) The standard edition of the complete psychological works of sigmund Freud, Vol XIV. Hogarth Press, London

Gabriel MT, Critelli JW, Ee JS (1994) Narcissistic illusions in self-evaluations of intelligence and attractiveness. J Personal 62(1):143-155. https://doi.org/10.1111/j.1467-6494.1994.tb00798.x

Galasso A, Simcoe TS (2011) CEO overconfidence and innovation. Manag Sci 57(8):1469-1484. https:// doi.org/10.1287/mnsc. 1110.1374

Gamache DL, McNamara G, Mannor MJ, Johnson RE (2015) Motivated to acquire? The impact of CEO regulatory focus on firm acquisitions. Acad Manag J 58(4):1261-1282. https://doi.org/10.5465/ amj.2013.0377

Gerstner W-C, König A, Enders A, Hambrick DC (2013) CEO Narcissism, audience engagement, and organizational adoption of technological discontinuities. Adm Sci Q 58(2):257-291. https://doi. org/10.1177/0001839213488773

Glaser M, Langer T, Weber M (2005) Overconfidence of professionals and lay men: Individual differences within and between tasks?

Graham JR, Harvey CR, Puri M (2013) Managerial attitudes and corporate actions. J Financ Econ 109(1):103-121. https://doi.org/10.1016/j.jfineco.2013.01.010

Griffin D, Tversky A (1992) The weighing of evidence and the determinants of confidence. Cognit Psychol 24(3):411-435. https://doi.org/10.1016/0010-0285(92)90013-R

Grijalva E, Harms PD, Newman DA, Gaddis BH, Fraley RC (2015a) Narcissism and leadership: a meta-analytic review of linear and nonlinear relationships. Pers Psychol 68(1):1-47. https://doi. org/10.1111/peps. 12072

Grijalva E, Newman DA, Tay L, Donnellan MB, Harms PD, Robins RW, Yan T (2015b) Gender differences in narcissism: a meta-analytic review. Psychol Bull 141(2):261-310. https://doi.org/10.1037/ a0038231

Grijalva E, Maynes TD, Badura KL, Whiting SW (2019) Examining the "I" in team: a longitudinal investigation of the influence of team narcissism composition on team outcomes in the NBA. Acad Manag J. https://doi.org/10.5465/amj.2017.0218

Ham C, Lang M, Seybert N, Wang S (2017a) CFO narcissism and financial reporting quality. J Account Res 51:1. https://doi.org/10.1111/1475-679X.12176

Ham C, Seybert N, Wang S (2017b) Narcissism is a bad sign: CEO signature size, investment, and performance. Rev Account Stud 69(1):241. https://doi.org/10.1007/s11142-017-9427-X

Hambrick DC, Mason PA (1984) Upper echelons: the organization as a reflection of its top managers. Acad Manag Rev 9(2):193-206. https://doi.org/10.5465/AMR.1984.4277628

Harris AJL, Corner A, Hahn U (2009) Estimating the probability of negative events. Cognition 110(1):51-64. https://doi.org/10.1016/j.cognition.2008.10.006

Harzing A-W, Alakangas S (2016) Google Scholar, Scopus and the Web of Science: a longitudinal and cross-disciplinary comparison. Scientometrics 106(2):787-804. https://doi.org/10.1007/s1119 2-015-1798-9

Hayward MLA, Hambrick DC (1997) Explaining the premiums paid for large acquisitions: evidence of CEO hubris. Adm Sci Q 42(1):103. https://doi.org/10.2307/2393810

Hayward MLA, Shepherd DA, Griffin D (2006) A Hubris theory of entrepreneurship. Manag Sci 52(2):160-172. https://doi.org/10.1287/mnsc.1050.0483

Hayward MLA, Forster WR, Sarasvathy SD, Fredrickson BL (2010) Beyond hubris: how highly confident entrepreneurs rebound to venture again. J Bus Ventur 25(6):569-578. https://doi.org/10.1016/j. jbusvent.2009.03.002

Herrmann P, Nadkarni S (2014) Managing strategic change: the duality of CEO personality. Strateg Manag J 35(9):1318-1342. https://doi.org/10.1002/smj.2156

Hilary G, Hsu C (2011) Endogenous overconfidence in managerial forecasts. J Account Econ 51(3):300313. https://doi.org/10.1016/j.jacceco.2011.01.002 
Hilary G, Hsu C, Segal B, Wang R (2016) The bright side of managerial over-optimism. J Account Econ 62(1):46-64. https://doi.org/10.1016/j.jacceco.2016.04.001

Hill AD, White MA, Wallace JC (2013) Unobtrusive measurement of psychological constructs in organizational research. Organ Psychol Rev 4(2):148-174. https://doi.org/10.1177/2041386613505613

Hill AD, Kern DA, White MA (2014) Are we overconfident in executive overconfidence research? An examination of the convergent and content validity of extant unobtrusive measures. J Bus Res 67(7):1414-1420. https://doi.org/10.1016/j.jbusres.2013.08.011

Hiller NJ, Hambrick DC (2005) Conceptualizing executive hubris: the role of (hyper-)core self-evaluations in strategic decision-making. Strateg Manag J 26(4):297-319. https://doi.org/10.1002/ smj.455

Hirshleifer D, Low A, Teoh SH (2012) Are overconfident CEOs better innovators? J Finance 67(4):14571498. https://doi.org/10.1111/j.1540-6261.2012.01753.x

Ho P-H, Huang C-W, Lin C-Y, Yen J-F (2016) CEO overconfidence and financial crisis: evidence from bank lending and leverage. J Financ Econs 120(1):194-209. https://doi.org/10.1016/j.jfine co.2015.04.007

Hribar P, Yang H (2016) CEO overconfidence and management forecasting. Contemp Account Res 33(1):204-227. https://doi.org/10.1111/1911-3846.12144

Humphery-Jenner M, Lisic LL, Nanda V, Silveri SD (2016) Executive overconfidence and compensation structure. J Financ Econ 119(3):533-558. https://doi.org/10.1016/j.jfineco.2016.01.022

Jensen MC, Meckling WH (1976) Theory of the firm: managerial behavior, agency costs and ownership structure. J Financ Econ 3(4):305-360. https://doi.org/10.1016/0304-405X(76)90026-X

Kahneman D, Tversky A (1979) Prospect theory: an analysis of decision under risk. Econometrica 47(2):263. https://doi.org/10.2307/1914185

Kallunki J-P, Pyykkö E (2013) Do defaulting CEOs and directors increase the likelihood of financial distress of the firm? Rev Account Stud 18(1):228-260. https://doi.org/10.1007/s11142-012-9203-X

Kaplan S, Sorensen M (2017) Are CEOs different? Characteristics of top managers. National Bureau of Economic Research, Cambridge

Kaplan SN, Klebanov MM, Sorensen M (2012) Which CEO characteristics and abilities matter? J Finance 67(3):973-1007. https://doi.org/10.1111/j.1540-6261.2012.01739.x

Kashmiri S, Nicol CD, Arora S (2017) Me, myself, and I: influence of CEO narcissism on firms' innovation strategy and the likelihood of product-harm crises. J Acad Mark Sci 45(5):633-656. https:// doi.org/10.1007/s11747-017-0535-8

Kennedy JA, Anderson C, Moore DA (2013) When overconfidence is revealed to others: testing the status-enhancement theory of overconfidence. Organ Behav Hum Decis Process 122(2):266-279. https://doi.org/10.1016/j.obhdp.2013.08.005

Kim YH (2013) Self attribution bias of the CEO: evidence from CEO interviews on CNBC. J Bank Finance 37(7):2472-2489. https://doi.org/10.1016/j.jbankfin.2013.02.008

Koch I, Biemann T (2014) Signs of narcissism of CEOs: validating a widely used measure. Acad Manag Proc 2014(1):16134. https://doi.org/10.5465/AMBPP.2014.16134abstract

Koellinger P, Minniti M, Schade C (2011) Excess entry and entrepreneurial decisions: the role of overconfidence. In: Minniti M (ed) The dynamics of entrepreneurship: Evidence from the global entrepreneurship monitor data. Oxford University Press, Oxford, pp 11-30. https://doi.org/10.1093/ acprof:oso/9780199580866.003.0002

Köhn A (2018) The determinants of startup valuation in the venture capital context: a systematic review and avenues for future research. Manag Rev Q 68(1):3-36. https://doi.org/10.1007/s1130 $1-017-0131-5$

Kohut H (1966) Forms and transformations of narcissism. J Am Psychoanal Assoc 14(2):243-272. https ://doi.org/10.1177/000306516601400201

Kolasinski AC, Li X (2013) Can strong boards and trading their own firm's stock help CEOs make better decisions? Evidence from acquisitions by overconfident CEOs. J Financ Quant Anal 48(04):11731206. https://doi.org/10.1017/S0022109013000392

Krippendorff K (1980) Content analysis: an introduction to its methodology, 3rd edn. Sage, London

Krizan Z, Bushman BJ (2011) Better than my loved ones: social comparison tendencies among narcissists. Personal Individ Differ 50(2):212-216. https://doi.org/10.1016/j.paid.2010.09.031

Kroll MJ, Toombs LA, Wright P (2000) Napoleon's tragic march home from Moscow: lessons in hubris. Acad Manag Perspect 14(1):117-128. https://doi.org/10.5465/AME.2000.2909844

Kruger J, Dunning D (1999) Unskilled and unaware of it: how difficulties in recognizing one's own incompetence lead to inflated self-assessments. J Personal Soc Psychol 77(6):1121-1134 
Lee JM, Hwang B-H, Chen H (2017) Are founder CEOs more overconfident than professional CEOs? Evidence from S\&P 1500 companies. Strateg Manag J 38(3):751-769. https://doi.org/10.1002/ smj.2519

Lewis FM, Daltroy LH (1990) How causal explanations influence health behavior: attribution theory. In: Health education and health behavior: theory research and practice. pp 92-114

Lubit R (2002) The long-term organizational impact of destructively narcissistic managers. Acad Manag Exec 16(1):127-138. https://doi.org/10.5465/AME.2002.6640218

Lumpkin GT, Dess GG (1996) Clarifying the entrepreneurial orientation construct and linking it to performance. Acad Manag Rev 21(1):135-172. https://doi.org/10.5465/AMR.1996.9602161568

Maccoby M (2000) Narcissistic leaders: the incredible pros, the inevitable cons. Harv Bus Rev 78:68-78

Maccoby M (2003) The productive narcissist: the promise and peril of visionary leadership, 1 st edn. Broadway Books, New York

Macenczak LA, Campbell S, Henley AB, Campbell WK (2016) Direct and interactive effects of narcissism and power on overconfidence. Personal Individ Differ 91:113-122. https://doi.org/10.1016/j. paid.2015.11.053

Mackey A (2008) The effect of CEOs on firm performance. Strateg Manag J 29(12):1357-1367. https ://doi.org/10.1002/smj.708

Malmendier U, Tate G (2005) CEO overconfidence and corporate investment. J Finance 60(6):26612700. https://doi.org/10.1111/j.1540-6261.2005.00813.x

Malmendier U, Tate G (2008) Who makes acquisitions? CEO overconfidence and the market's reaction? J Financ Econ 89(1):20-43. https://doi.org/10.1016/j.jfineco.2007.07.002

Malmendier U, Tate G, Yan J (2011) Overconfidence and early-life experiences: the effect of managerial traits on corporate financial policies. J Finance 66(5):1687-1733. https://doi.org/10.111 1/j.1540-6261.2011.01685.x

Markovitch DG, Steckel JH, Michaut A, Philip D, Tracy WM (2015) Behavioral reasons for new product failure: Does overconfidence induce overforecasts? J Prod Innov Manag 32(5):825-841. https://doi.org/10.1111/jpim.12252

Mathieu C, St-Jean É (2013) Entrepreneurial personality: the role of narcissism. Personal Individ Differ 55(5):527-531. https://doi.org/10.1016/j.paid.2013.04.026

McCarthy S, Oliver B, Song S (2017) Corporate social responsibility and CEO confidence. J Bank Finance 75:280-291. https://doi.org/10.1016/j.jbankfin.2016.11.024

McGahan AM, Porter ME (1997) How much does industry matter, really? Strateg Manag J 18:15-30

McKenny AF, Short JC, Payne GT (2013) Using computer-aided text analysis to elevate constructs. Organ Res Methods 16(1):152-184. https://doi.org/10.1177/1094428112459910

Miller D (2015) A downside to the entrepreneurial personality? Entrep Theory Pract 39(1):1-8. https ://doi.org/10.1111/etap.12130

Mintzberg H (1971) Managerial work: analysis from observation. Manag Sci 18(2):B-97-B-110. https ://doi.org/10.1287/mnsc.18.2.B97

Moore DA, Healy PJ (2008) The trouble with overconfidence. Psychol Rev 115(2):502-517. https:// doi.org/10.1037/0033-295X.115.2.502

Morf CC, Rhodewalt F (2001) Unraveling the paradoxes of narcissism: a dynamic self-regulatory processing model. Psychol Inq 12(4):177-196. https://doi.org/10.1207/S15327965PLI1204_1

Morris JA, Brotheridge CM, Urbanski JC (2005) Bringing humility to leadership: antecedents and consequences of leader humility. Hum Relat 58(10):1323-1350. https://doi.org/10.1177/00187 26705059929

Mullins W, Schoar A (2016) How do CEOs see their roles? Management philosophies and styles in family and non-family firms. J Financ Econ 119(1):24-43. https://doi.org/10.1016/j.jfine co.2015.08.011

Nag R, Hambrick DC, Chen M-J (2007) What is strategic management, really? Inductive derivation of a consensus definition of the field. Strateg Manag J 28(9):935-955. https://doi.org/10.1002/ smj.615

Navis C, Ozbek OV (2015) The right people in the wrong places: the paradox of entrepreneurial entry and successful opportunity realization. Acad Manag Rev 41(1):109-129. https://doi.org/10.5465/ amr.2013.0175

Nelson RR, Winter SG (1982) An evolutionary theory of economic change. The Belknap Press of Harvard University Press, Cambridge 
Nevicka B, de Hoogh AHB, van Vianen AEM, Beersma B, McIlwain D (2011) All I need is a stage to shine: Narcissists' leader emergence and performance. Leadersh Q 22(5):910-925. https://doi. org/10.1016/j.leaqua.2011.07.011

Odean T (1999) Do investors trade too much? Am Econ Rev 89(5):1279-1298. https://doi.org/10.1257/ aer.89.5.1279

O'Reilly CA, Doerr B, Caldwell DF, Chatman JA (2014) Narcissistic CEOs and executive compensation. Leadersh Q 25(2):218-231. https://doi.org/10.1016/j.leaqua.2013.08.002

O'Reilly CA, Doerr B, Chatman JA (2017) "See you in court": how ceo narcissism increases firms' vulnerability to lawsuits. Leadersh Q. https://doi.org/10.1016/j.leaqua.2017.08.001

Ou AY, Waldman DA, Peterson SJ (2016) Do humble CEOs matter? an examination of CEO humility and firm outcomes. J Manag 49(2):014920631560418. https://doi.org/10.1177/0149206315604187

Parris DL, Peachey JW (2013) A systematic literature review of servant leadership theory in organizational contexts. J Bus Ethics 113(3):377-393. https://doi.org/10.1007/s10551-012-1322-6

Patel PC, Cooper D (2014) The harder they fall, the faster they rise: approach and avoidance focus in narcissistic CEOs. Strateg Manag J 35(10):1528-1540. https://doi.org/10.1002/smj.2162

Paul J, Criado AR (2020) The art of writing literature review: What do we know and what do we need to know? Int Bus Rev 29(4):101717. https://doi.org/10.1016/j.ibusrev.2020.101717

Paulhus DL, Harms PD, Bruce MN, Lysy DC (2003) The over-claiming technique: measuring selfenhancement independent of ability. J Personal Soc Psychol 84(4):890-904. https://doi. org/10.1037/0022-3514.84.4.890

Peterson RS, Smith DB, Martorana PV, Owens PD (2003) The impact of chief executive officer personality on top management team dynamics: one mechanism by which leadership affects organizational performance. J Appl Psychol 88(5):795-808. https://doi.org/10.1037/0021-9010.88.5.795

Peterson SJ, Galvin BM, Lange D (2012) CEO servant leadership: exploring executive characteristics and firm performance. Pers Psychol 65(3):565-596. https://doi.org/10.1111/j.1744-6570.2012.01253.x

Petrenko OV, Aime F, Ridge J, Hill A (2016) Corporate social responsibility or CEO narcissism? CSR motivations and organizational performance. Strateg Manag J 37(2):262-279. https://doi. org/10.1002/smj. 2348

Post JM (1986) Narcissism and the charismatic leader-follower relationship. Polit Psychol 7(4):675. https ://doi.org/10.2307/3791208

Post JM (1993) Current concepts of the narcissistic personality: implications for political psychology. Polit Psychol 14(1):99. https://doi.org/10.2307/3791395

Raskin R, Novacek J, Hogan R (1991) Narcissism, self-esteem, and defensive self-enhancement. J Personal 59(1):19-38. https://doi.org/10.1111/j.1467-6494.1991.tb00766.x

Resick CJ, Whitman DS, Weingarden SM, Hiller NJ (2009) The bright-side and the dark-side of CEO personality: examining core self-evaluations, narcissism, transformational leadership, and strategic influence. J Appl Psychol 94(6):1365-1381. https://doi.org/10.1037/a0016238

Rijsenbilt A, Commandeur H (2013) Narcissus enters the courtroom: CEO narcissism and fraud. J Bus Ethics 117(2):413-429. https://doi.org/10.1007/s10551-012-1528-7

Roll R (1986) The hubris hypothesis of corporate takeovers. J Bus 59(2):197. https://doi. org/10.1086/296325

Rosenthal SA, Pittinsky TL (2006) Narcissistic leadership. Leadersh Q 17(6):617-633. https://doi. org/10.1016/j.leaqua.2006.10.005

Roy MM, Liersch MJ (2013) I am a better driver than you think: examining self-enhancement for driving ability. J Appl Soc Psychol 43(8):1. https://doi.org/10.1111/jasp.12117

Schaefer PS, Williams CC, Goodie AS, Campbell WK (2004) Overconfidence and the big five. J Res Personal 38(5):473-480. https://doi.org/10.1016/j.jrp.2003.09.010

Schrand CM, Zechman SLC (2012) Executive overconfidence and the slippery slope to financial misreporting. J Account Econ 53(1-2):311-329. https://doi.org/10.1016/j.jacceco.2011.09.001

Sears DO (1986) College sophomores in the laboratory: influences of a narrow data base on social psychology's view of human nature. J Personal Soc Psychol 51(3):515-530. https://doi. org/10.1037/0022-3514.51.3.515

Shipman AS, Mumford MD (2011) When confidence is detrimental: influence of overconfidence on leadership effectiveness. Leadersh Q 22(4):649-665. https://doi.org/10.1016/j.leaqua.2011.05.006

Short J (2009) The art of writing a review article. J Manag 35(6):1312-1317. https://doi. org/10.1177/0149206309337489

Shulman ME (2016) “The economy's favored children": the narcissistic relation and the financial crisis. Int J Appl Psychoanal Stud 13(1):24-52. https://doi.org/10.1002/aps.1408 
Simon M, Houghton SM (2003) The relationship between overconfidence and the introduction of risky products: evidence from a field study. Acad Manag J 46(2):139-149. https://doi.org/10.2307/30040 610

Smith MB, Hill AD, Wallace JC, Recendes T, Judge TA (2017) Upsides to dark and downsides to bright personality: a multidomain review and future research agenda. J Manag. https://doi. org/10.1177/0149206317733511

Spain SM, Harms P, LeBreton JM (2014) The dark side of personality at work. J Organ Behav 35(S1):S41-S60. https://doi.org/10.1002/job.1894

Syverson C (2004) Product substitutability and productivity dispersion. Rev Econ Stat 86(2):534-550. https://doi.org/10.1162/003465304323031094

Syverson C (2011) What determines productivity? J Econ Lit 49(2):326-365. https://doi.org/10.1257/ jel.49.2.326

Tang Y, Li J, Yang H (2015) What i see, what i do: how executive hubris affects firm innovation. J Manag 41(6):1698-1723. https://doi.org/10.1177/0149206312441211

Tang Y, Mack DZ, Chen G (2018) The differential effects of CEO narcissism and hubris on corporate social responsibility. Strateg Manag J 84(3):191. https://doi.org/10.1002/smj.2761

The New York Times (2002) 2 Top tyco executives charged with $\$ 600$ million fraud scheme. Retrieved from https://www.nytimes.com/2002/09/13/business/2-top-tyco-executives-charged-with-600-milli on-fraud-scheme.html

Tranfield D, Denyer D, Smart P (2003) Towards a methodology for developing evidence-informed management knowledge by means of systematic review. Br J Manag 14(3):207-222. https://doi. org/10.1111/1467-8551.00375

Trevelyan R (2008) Optimism, overconfidence and entrepreneurial activity. Manag Decis 46(7):9861001. https://doi.org/10.1108/00251740810890177

Trigeorgis L, Reuer JJ (2017) Real options theory in strategic management. Strateg Manag J 38(1):42-63. https://doi.org/10.1002/smj.2593

Wales WJ, Patel PC, Lumpkin GT (2013) In pursuit of greatness: CEO narcissism, entrepreneurial orientation, and firm performance variance. J Manag Stud 50(6):1041-1069. https://doi.org/10.1111/ joms. 12034

Watts AL, Lilienfeld SO, Smith SF, Miller JD, Campbell WK, Waldman ID, Faschingbauer TJ (2013) The double-edged sword of grandiose narcissism: implications for successful and unsuccessful leadership among U.S. Presidents. Psychol Sci 24(12):2379-2389. https://doi.org/10.1177/09567 97613491970

Webster. definition of overconfidence. Retrieved from https://www.merriam-webster.com/dictionary/ overconfidence

Zhang H, Ou AY, Tsui AS, Wang H (2017) CEO humility, narcissism and firm innovation: a paradox perspective on CEO traits. Leadersh Q 1:1. https://doi.org/10.1016/j.leaqua.2017.01.003

Zhu DH, Chen G (2014) CEO narcissism and the impact of prior board experience on corporate strategy. Adm Sci Q 60(1):31-65. https://doi.org/10.1177/0001839214554989

Zhu DH, Chen G (2015) Narcissism, director selection, and risk-taking spending. Strateg Manag J 36(13):2075-2098. https://doi.org/10.1002/smj.2322

Zupic I, Čater T (2015) Bibliometric methods in management and organization. Organ Res Methods 18(3):429-472. https://doi.org/10.1177/1094428114562629

Publisher's Note Springer Nature remains neutral with regard to jurisdictional claims in published maps and institutional affiliations. 